The United Nations

University

\title{
WIDER
}

World Institute for Development Economics Research

Research for Action 51

Communist and Transitory Income Distribution and Social Structure in the Czech Republic

Jiri Večernik 
UNU World Institute for

Development Economics Research

(UNU/WIDER)

\title{
Research for Action 51
}

\section{Communist and Transitory Income Distribution and Social Structure in the Czech Republic}

\author{
Jiří Večerník
}

This study has been prepared within the UNU/WIDER project on Income Distribution and Social Structure during the Transition, which is directed by Dr Vladimir Mikhalev.

UNU/WIDER gratefully acknowledges the financial contribution to the project by the Government of Sweden (Swedish International Development Cooperation Agency Sida).

Jiří Večerník is affiliated with the Institute of Sociology, Academy of Sciences of the Czech Republic, Prague. 
UNU World Institute for Development Economics Research (UNU/WIDER)

A research and training centre of the United Nations University

\section{The Board of UNU/WIDER}

Nora Lustig

Harris Mutio Mule

Sylvia Ostry

Jukka Pekkarinen, Vice Chairperson

George Vassiliou, Chairperson

Ruben Yevstigneyev

Masaru Yoshitomi

\section{Ex Officio}

Hans J. A. van Ginkel, Rector of UNU

Giovanni Andrea Cornia, Director of UNU/WIDER

UNU World Institute for Development Economics Research (UNU/WIDER) was established by the United Nations University as its first research and training centre and started work in Helsinki, Finland in 1985. The purpose of the Institute is to undertake applied research and policy analysis on structural changes affecting the developing and transitional economies, to provide a forum for the advocacy of policies leading to robust, equitable and environmentally sustainable growth, and to promote capacity strengthening and training in the field of economic and social policy making. Its work is carried out by staff researchers and visiting scholars in Helsinki and through networks of collaborating scholars and institutions around the world.

UNU World Institute for Development Economics Research (UNU/WIDER)

Katajanokanlaituri 6 B

00160 Helsinki, Finland

\section{Copyright (C) UNU/WIDER 1999}

Camera-ready typescript prepared by Janis Vehmaan-Kreula at UNU/WIDER

Printed at Hakapaino Oy, Helsinki

The views expressed in this publication are those of the author(s). Publication does not imply endorsement by programme/project sponsors, the Institute or the United Nations University of any of the views expressed.

ISSN 1239-6761

ISBN 952-9520-95-6 (printed publication)

ISBN 952-455-037-7 (internet publication) 


\section{CONTENTS}

LIST OF TABLES AND FIGURES iv

FOREWORD vi

ABSTRACT vii

ACKNOWLEDGEMENTS $\quad$ ix

I SOCIAL STRUCTURE PRIOR TO THE TRANSITION 1

1.1 Working class: upwards 1

1.2 Middle classes: downwards 2

1.3 Social structure: statistics and reality 2

1.4 The first sociological studies 4

1.5 Social mobility 5

1.6 Income inequality 5

$\begin{array}{llr}1.7 & \text { Poverty } & 8\end{array}$

II SOCIAL CLASSES AND INCOMES IN THE TRANSITION PROCESS 10

$\begin{array}{lll}2.1 & \text { Economic, social and political reforms } & 10\end{array}$

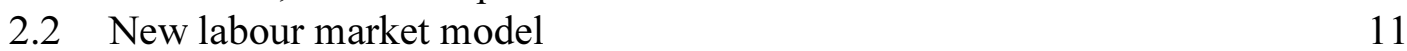

$\begin{array}{ll}2.3 \text { Budgetary policy } & 12\end{array}$

2.4 The growth of the private sector of the economy 13

$\begin{array}{ll}2.5 & \text { Informalization and demonetization } \\ & 13\end{array}$

2.6 The rise in income inequality 14

$\begin{array}{lll}2.7 & \text { Redistribution of income } & 17\end{array}$

III EMERGING NEW SOCIAL STRATIFICATION 20

3.1 Determinants of social stratification $\quad 20$

$\begin{array}{ll}3.2 \text { Old and new elites } & 22\end{array}$

$\begin{array}{lll}3.3 & \text { Middle classes } & 23\end{array}$

3.4 Manual workers and farmers 26

$\begin{array}{ll}3.5 & \text { The poor and socially deprived } \\ \end{array}$

IV SOCIAL RE-RANKING, STATUS INCONSISTENCY AND
POLARIZATION

4.1 Objective mobility 30

$\begin{array}{lll}4.2 & \text { Subjective mobility } & 32\end{array}$

4.3 Status inconsistency 34

4.4 Social re-ranking in 1989-99 36

4.5 The social costs of transformation 36

V CONCLUSION 41

DATA SOURCES 44

APPENDIX TABLES AND FIGURES 45

REFERENCES 


\section{LIST OF TABLES AND FIGURES}

$\underline{\text { Tables }}$

Table 1.1 Composition of households and incomes according to 'social group' 3

Table 1.2a Current class position of respondent according to his/her first class position

Table 1.2b Current class position of respondent according to his/her father's class position

Table 1.3 Earnings and households incomes (quantile characteristics in per cent of median)

Table 2.1 Characteristics of distribution of household income

Table 2.2 Distribution of household income according to decile shares and real growth

Table 2.3 Analysis of variance of (ln) household income (per cent of total variance)

$\begin{array}{lll}\text { Table 2.4 Relative taxes and social benefits according to decile shares } & 18\end{array}$

Table 3.1 Opinions about factors of life success (index)

Table 3.2 Characteristics of the economic elite according to sector of ownership (directors)

Table 3.3 Branch structure of earnings in two historical periods

Table 3.4 Economically active population and earnings according to education 26

Table 3.5 Poor households and persons according to family status

Table 4.1 Class structure of economically active population in the age group $20-65$

Table 4.2 Intragenerational class mobility of persons in working age

Table 4.3 Subjective mobility of economically active persons

Table 4.4 Subjective mobility of economically active persons who have not changed their social class between 1988-93

Table 4.5 Objective status consistency: the results of exploratory factor analysis method: principal components analysis, OBLIMIN rotation, pattern matrices 
Table 4.6a Self-ranking according to social position, income and standard of living

Table 4.6b Change in self-ranking according to social position, income and standard of living (mean change in points of the decile scale)

Table 4.7 Correlation of self-ranking according to social position, income and standard of living in 1999 and their change in 1989-99 with characteristics of respondents (Spearman coefficients)

\section{$\underline{\text { Figures }}$}

Figure 3.1 Poverty will be acute in the near future

Figure 3.2 Consider themselves a poor family

Figure 4.1 Declared financial difficulties of households

Figure 4.2 Perception of conflicts between various categories

Appendix tables and figures

Table A1 Employed persons according to the branch of employment 45

Table A2 Earnings according to the branch of employment 45

Figure A1 Real incomes in 1990-97 46

Figure A2 Incomes of the population according to their source 46 


\section{FOREWORD}

In Eastern Europe the transition to the market economy has been accompanied by deep economic and social transformations. In many countries of the region, the reforms were accompanied by a fall in living standards, a rise in unemployment, increases in asset and earning inequality and sharp deteriorations in well-being. Several social groups lost both in absolute terms and in terms of their relative position in the social ladder. One major outcome of this transformation is a considerable re-ranking among social classes and mounting distance between the new emerging social classes. Thus, social structure is evolving from an egalitarian pattern to a highly stratified one.

This process of social stratification varies substantially among transitional countries. For instance, in comparatively successful reformers social structure remained relatively stable. Such is the case of the Czech Republic, analysed in this study by Jiří Večerník. This country is known as a radical but consistent reformer. Unlike elsewhere in the region, it experienced a modest recession and an immediate - if slow - recovery. The country performed well also in welfare terms: real wages and incomes were little affected, inequality rose modestly, and still is among the lowest in the world, and a comprehensive and well-targeted social transfer systems offset much of the unavoidable dislocations caused by the transition. As a result, the Czech Republic managed to avoid massive social dislocations, which occurred elsewhere in the region, and preserved the social cohesion essential to sustain market reforms and democratization.

This study by Jiří Večerník offers a comprehensive account of the changes in social structure in the Czech Republic during the past decade. The study is based on original statistical and sociological data which allowed a detailed analyse of the social transformation. The study concludes that the Czech society experienced a much less pronounced social polarization than other transitional societies and - unlike Poland and Hungary where the formation of the new capitalist and middle class is the most intensive - preserved much of its old social structure. Dr Večerník underscores in particular the key role acquired by the new young industrial managers - the core of the economic elite - who often occupied positions of deputies-directors under the old regime. In contrast, the prospects of the nascent new middle class appear to have remained limited. Readers will find many other interesting findings in this work supported by rich factual and statistical material.

Giovanni Andrea Cornia Director, UNU/WIDER December 1999 


\begin{abstract}
Statistical and sociological evidence is gathered to display changes in social structure of the Czech society before and after 1989, with a special focus on economic inequalities. In the first part, frozen landscape of the communist regime is observed. Behind the facade of forced social homogeneity, privileges of party nomenclatura on the one hand and poverty of sections of the population excluded by the 'class war' on the other hand took place. Within the narrow range of earnings, preferential treatment was given to heavy manufacturing, manual occupations and the generation of 'founding fathers' of the communist regime. Along with the equalized wages, various sources of extra income developed which caused larger hidden disparities.
\end{abstract}

In the second part, after the 1989 reforms are described which liberalized labour market and introduced a new system of social protection, with guaranteed living minimum as a core. Privatization brought about small entrepreneurs on the economic scene and opened new opportunities. Fed by both rising disparities of wages and business income, the distribution of household income became considerably larger, mostly due to rapidly increasing highest incomes. Among income predictors, the importance of labour market characteristics of economically active individuals reinforces instead of demographic characteristics of households which dominated until 1989. In redistribution of income through taxes and benefits, the progressiveness of financial flows strengthens as the system moves from family life-cycle to labour-market shape.

In the third part, the sources and groups of emerging new social stratification are described. While the political elite was exchanged almost completely, recruitment of the economic elite can be rather called a 'revolution of deputies'. Regarding small entrepreneurs, the system was not very supportive, unlike generously credited former state firms. Regarding white collars, expectations concerning the return to their previous position have been left unfulfilled: the rise of financial sector and public administration contrasts with the stagnation of education and health services. Up to now, the degree of social deprivation is generally low in the Czech Republic, what is caused by still quite low levels of income disparities, the good performance of the social system and until 1997 also the economy. The exception is the Roma ethnic, extremely vulnerable to all the risks of the market economy.

In the fourth part, various mobility flows are observed. While objective changes in socio-economic composition of the economically active population are significant but far from impressive, there is much more subjective movements, reflecting among other collective mobility. In comparison with its reforming neighbours, the Czech population declared the most stability and upwards mobility. Data also witness growing consistency of education, job and income as well as strengthening links between the objective situation and subjective location in the social hierarchy. Regarding social cohesion as it is indicated by perceived levels of conflicts, there has not been significant increase over time which would signal social polarization of the society. 
In the conclusion, limited expansion of the middle class is stressed as the main failure of the development after 1989. The government was much more interested in the transformation of existing enterprises than in the creation of favourable conditions for the new entrepreneurs. It allowed the expansion of the financial and administrative sectors but it neglected the public services of health, education and research. It turned out that in fact, the new political elite concluded the imaginary social contract with the upper strata - financial capital, top management and bureaucracy, many of whose members belonged to the former nomenclatura- rather than with the middle class. This was reflected by a shifting of opinions and voters' preferences to the left and by increasing expectations of state protection. 


\section{ACKNOWLEDGEMENTS}

This paper was written in the framework of the UNU/WIDER project Income Distribution and Social Structure during the Transition. I express all my gratitude to the initiator of the project Giovanni Andrea Cornia and the head of the project Vladimir Mikhalev who were also helpful with their comments and suggestions in finalizing the paper, together with Ivan Szelenyi and other participants of the project meeting in Helsinki in May 1999. My thankfulness is due also to Janis Vehmaan-Kreula who kindly conducted English editing. In the paper, along with my own computations, I largely used analyses of stratification data, made by my closest colleague Petr Mateju. 


\section{SOCIAL STRUCTURE PRIOR TO THE TRANSITION}

The communist putsch in 1948 triggered a complete transformation of the economic and social structures of the Czechoslovak society. At that time, it was an economically advanced country (especially Czech lands) with a democratic political system, although limited due to the post-war pressure of the Communist Party, backed by the Soviet regime and army. Socially, it was a relatively homogeneous middle-class society in which petty bourgeoisie and white collar workers represented large sections of the population, serving as reference groups for the rest of the society. Up until 1948, only little had changed in the social structure since the mid-1930s when the Czech society was characterized (with some exaggeration) as 'almost one homogeneous strata of urban workers and employees with very similar living conditions and mentality corresponding to the unified mass culture of today' (Ullrich 1937: 43).

\subsection{Working class: upwards}

Instead of supporting the middle classes, the communist regime tried to equalize society around the working class. It proceeded by eliminating entrepreneurs and the selfemployed, limiting services, collectivizing peasantry and degrading the 'intelligentsia' in rewards and prestige. Unlike East Germany, Hungary and Poland, small entrepreneurs and private farmers were eradicated completely in Czechoslovakia. Wage disparities were attenuated in general as severely as in East Germany (which was the most equalized country) and according to education more than elsewhere. Within the working class itself, its traditional sections of skilled workers in light manufacturing experienced degradation (accompanied by large feminization and a corresponding wage decrease), while new sections of mining and heavy industry were promoted, following the plan to transform Czechoslovakia into a 'smithy of the socialist camp'.

The communist regime insisted that the new system was designed for the working class, which was allowed to dominate society and to govern it economically and politically. Because Marx's prophecy about the automatic elimination of all social groups located between the proletariat and bourgeoisie were not fulfilled, his later socialist disciples tried to assert it by the forceful homogenization of society into one 'aggregate worker'. Working class hegemony was certainly real if we consider the fact that living conditions of the entire society were intended to be reduced to the lowest common denominator and lifestyle of the working class was intended to prevail. It was, however, fictitious in the realm of political rule. In fact, it only endorsed the communist regime and facilitated the totalitarian control of society by a small ruling class. ${ }^{1}$

1 Concept of social hegemony used here is inspired by Antonio Gramsci but not in its narrow political and power sense. According to Gramsci, the function of 'social hegemony' in civil society comprises the 'spontaneous' consent given by the great masses of the population to the general direction imposed on social life by the dominant fundamental group (Gramsci 1971). We give a broader meaning to this concept 


\subsection{Middle classes: downwards}

As the middle classes by their mere existence represented a challenge to the Marxist orthodoxy and were considered to be harmful to the functioning of the communist regime, it sought to squeeze them to the margins of social and economic life. They were systematically eliminated in reality (by the confiscation of private property and forced shifts in the labour force), in statistical terms (by manipulating occupational groups and deliberately merging them into conglomerates of the 'working class' and 'other employees') and in the collective memory (by designating the petty bourgeoisie as a reactionary element condemned by the iron laws of history to disappear, and by stigmatizing the intelligentsia as an unreliable and suspect strata).

Despite all the pressures of homogenization of society and equalizing the level of living, differences among people did not disappear completely. Many remain in reality but most disappeared from the statistics. Social statistics say virtually nothing about the main changes in the early 1950s. After a political break, statistics reappeared again in the late 1950 s in a completely new form, tailored according to Soviet classifications. The social categories observed systematically by statistics from this time were only the working class, 'other employees', cooperative peasants and pensioners (with private peasants and the self-employed as a negligible remainder).

\subsection{Social structure: statistics and reality}

In the $1970 \mathrm{~s}$ and $1980 \mathrm{~s}$, statistics continued to describe the population according to established categories. As Table 1.1 shows, the 'working class' saw many changes in the 1970 s but decreased somewhat in the 1980s, in favour of 'other employees'. The 'class of cooperative peasants' was kept stable over the entire period. Also, the share of pensioners did not change, and even decreased during the last communist decades, due to an advantageous age structure. The statistical picture shows a frozen land of big 'brotherhood' classes while the categories of self-employed represented a fraction of the population.

In the period of normalization coming with Soviet tanks after the reform attempt of 1968 Prague Spring, illusions that functional inequalities would assert themselves in economic life were discarded and economic disparities returned back into the darkness of private life and political privileges. Behind the statistics, however, there were 'additional' sources of well-being and inequality:

In kind incomes. Due to the very low real incomes, food expenditures were a substantial drain on household budgets (decreasing only from about 45 per cent to 30 per cent over the long period of 1948-88). Any opportunity to economize in this area constituted a special advantage and considerably increased a family's general welfare. After the 'class of cooperative peasants' was formed by the forceful collectivization of land and farming facilities, its members were privileged by being able to retain pieces of land where food

in the sense that the 'hegemonical' class might also be those whose values shaped the development of the society (Večerník 1999a). 
TABLE 1.1

COMPOSITION OF HOUSEHOLDS AND INCOMES ACCORDING TO 'SOCIAL GROUP' (per cent)

\begin{tabular}{lrrrrrr}
\hline \multicolumn{1}{c}{ Social group } & 1970 & 1976 & 1980 & 1988 & 1992 & 1996 \\
\hline Composition of households & & & & & & \\
Manual workers & 40.7 & 40.9 & 41.1 & 34.5 & 30.0 & 30.3 \\
Other employees & 25.0 & 26.3 & 26.8 & 31.6 & 24.9 & 25.1 \\
Cooperative farmers & 5.4 & 4.7 & 5.1 & 5.6 & 3.0 & 0.6 \\
Private farmers & 0.3 & 0.1 & 0.0 & 0.0 & 0.5 & 0.6 \\
Self-employed & 0.1 & 0.1 & 0.1 & 0.2 & 5.8 & 8.7 \\
Pensioners & 28.1 & 27.5 & 26.2 & 27.7 & 34.2 & 32.3 \\
Other & 0.4 & 0.4 & 0.7 & 0.4 & 1.6 & 2.3 \\
Total & 100.0 & 100.0 & 100.0 & 100.0 & 100.0 & 100.0 \\
\hline Household income per capita & & & & & & \\
Manual workers & 98.1 & 96.8 & 98.0 & 103.2 & 95.6 & 93.0 \\
Other employees & 113.8 & 112.9 & 111.7 & 112.3 & 117.7 & 124.2 \\
Cooperative farmers & 108.0 & 105.4 & 104.7 & 108.9 & 91.4 & 89.4 \\
Private farmers & - & - & - & - & - & 125.0 \\
Self-employed & - & - & - & - & 142.6 & 127.9 \\
Pensioners & 81.4 & 86.2 & 83.5 & 80.4 & 85.8 & 83.2 \\
Total & 100.0 & 100.0 & 100.0 & 100.0 & 100.0 & 100.0 \\
\hline
\end{tabular}

Sources: Microcensuses 1970-96.

could be produced, either for private consumption or for the market. At the same time, in most agricultural cooperatives, in-kind income was received as a partial payment replacing money.

The informal economy. A huge reduction in the service sector directly provoked a demand for the work of craftsmen while a scarcity of consumer goods provided salesmen who could then charge higher prices, with an opportunity for greater profit. The black market encompassed a wide range of services, including those in the social sector, be it in health care, education, the allocation of apartments, the provision of departure visas, and so on. While new 'triumph of communism' were officially announced, the list of informal activities extended further; if scarcity had not occurred 'spontaneously', it would simply have been provoked deliberately in order to exploit it at a later stage. ${ }^{2}$

Party privileges. Special rewards were necessary for the 'special kind of people' (as the Czech communists once called themselves). Party officials enjoyed privileges such as free or very cheap goods, services and goods unavailable to the ordinary citizen

2 On this point we disagree with Sik (1995: 48), who asserts that the informal economy under the communist regime caused an insignificant increase in income inequality. Opportunities and the moral liberty to use them were distributed rather unevenly from top to bottom of the socio-political scale. 
(including special stores, health services and recreation areas) which increased their purchasing power much more than any official rise in earnings.

Hidden ownership rights. Although private ownership of the means of production did not officially exist under the communist regime, in actual fact owners did. Managers, administrators, directors, party officials had extensive opportunities and incentives to misuse their economic power and transform the ownership status of many goods from state to private, as well as enjoying greater benefits from public services. ${ }^{3}$

Extreme inequalities in housing costs, for instance, were fed by all the above mentioned sources. In the countryside, cooperative materials, machines and working hours were usually used for the construction of individual houses. Informal economy networks were also often used to build the family house or buy an apartment. The politically privileged groups were given first option on state apartments originally aimed at solving the housing needs of low income families and, then, distributed free of charge. A frequent form of ownership transfer was the purchase of a house for an 'official' (often symbolic) price by a manager or party bureaucrat. The same practice was used with apartments left by political emigrants.

\subsection{The first sociological studies}

In order not to allow the data to confront the ideology, a closer insight into structures and mobility was hindered - for example, wage disparities according to age and education were never inquired into by the Statistical Office until 1967. Quite obviously, the most confidential was the most important rift of the society - between the nomenclatura and 'the people'. The special rewards and privileges, the internal careers and networks of the upper few were a complete mystery for the population. This also allowed the new garniture of communist leaders of 1968 to present their 'human face' to the naive population and feed its illusions about possible change of the system - and then betray the people again after the Soviet tanks came in August 1968.

However, in the atmosphere of loosening up of the communist regime, the first survey on social stratification was conducted in 1967 (as late as four years after the first one in Hungary). Sociologists, using data in determined patterns, found that the society was stratified according to the complexity of work, level of education and quality of lifestyle which altogether created the main axis of social stratification. However, the core of differences appeared to be situated in the intimate sphere of family life rather than in the public sphere of job position. The interpretation was framed by the concept of industrial society, presenting the most advanced socialist countries as a quite successful alternative to the Western market society (Machonin et al. 1969).

3 It was not only the top politicians, but also regional or district 'rulers' (directors of big enterprises and cooperatives, party secretaries) who used their earnings almost only for saving because they got everything else free of charge, according to the unwritten rules of providing for the powerful. The list begun with meat (a scarce item at the time) and ended with housing. 
In spite of the fact that two large surveys of the 'class structure' were allowed in the period of 'normalization' (in 1978 and 1984), no systematic analysis of social stratification and mobility occurred. Partly, this was because of the frozen climate at that time and the domination of the old Marxist dogmatism, and partly because of the reluctance of leading administrators of social research anxious about the eventual results not much corresponding to the main 'political line' - in which the maxim was social homogenization. The data were used rather selectively, concretely for analysis of educational mobility by Petr Mateju and income inequality by Jiří Večerník.

\subsection{Social mobility}

By intention, the communist system tried to turn the pyramid of society upside down, encouraging especially manual workers (by position or origin) and directing them to higher education and, consequently, to managerial positions. In the $1950 \mathrm{~s}$, 'new intelligentsia' was expressly trained in several-month courses (such as lawyers) and class origin was started to be systematically used for affirmative action in favour of working class children. The result of this equalization strategy is however surprising: viewed retrospectively, it had in the end only little effect. Petr Mateju documents on the data of 1984 stratification survey that various social classes succeeded in access to higher education in the same degree as previously. Whereas the administratively based redistribution failed to attenuate social inequality in educational attainment, it however succeeded in weakening transparent competition and devastated the educational system (Mateju 1991).

Matrices in Table 1.2 ( $a$ and $b$ ) show the summarized picture of social mobility during the communist period. In the intergenerational perspective, the dual recruitment of the 'upper' class of professionals of that time is apparent: one half had non-manual fathers, the other skilled and unskilled manual fathers. From the other side, 75 per cent of respondents having a professional father stayed in non-manual jobs. The climbing of working class children into non-manual jobs was also considerable (nearly half of skilled workers and about a third of unskilled), mostly due to the changing occupational structure. In the intragenerational perspective, stability prevailed among professionals and was considerable also among routine non-manual and unskilled manual workers. About a fifth of skilled manual workers climbed to non-manual occupations, which was a well-advertised path supported by evening classes.

\subsection{Income inequality}

An analysis of income distribution showed that contrary to the rhetoric's about the importance of rewards as work motivation ('each according to his capacity, to each according to his work'), disparities in both earnings and income followed rather demographic characteristics of workers (sex and age) and of households (numbers of economically active members and dependent children). Because disparities in earnings were kept stable since the end of 1950, the distribution of household income changed according to the demographic composition of households (Večerník 1976). But in the 1970s and 1980s, no important change was found either in the distribution of wages or in inequality of household income (Table 1.3). 
TABLE 1.2a

CURRENT CLASS POSITION OF RESPONDENT ACCORDING TO HIS/HER

FIRST CLASS POSITION (per cent)

\begin{tabular}{lcccccrc}
\hline $\begin{array}{l}\text { First/ } \\
\text { Current }\end{array}$ & $\begin{array}{c}\text { Profes- } \\
\text { sionals }\end{array}$ & $\begin{array}{c}\text { Routine } \\
\text { non- } \\
\text { manual }\end{array}$ & $\begin{array}{c}\text { Inde- } \\
\text { pendent }\end{array}$ & $\begin{array}{c}\text { Private } \\
\text { farmers }\end{array}$ & $\begin{array}{c}\text { Skilled } \\
\text { manual }\end{array}$ & $\begin{array}{c}\text { Un- and } \\
\text { semi-skilled }\end{array}$ & $\begin{array}{c}\text { Agricult. } \\
\text { workers }\end{array}$ \\
\hline Professionals & 65.5 & 11.6 & 0.0 & 0.5 & 16.0 & 5.4 & 1.0 \\
& 89.4 & 10.0 & 0.0 & 3.4 & 11.2 & 3.7 & 2.4 \\
Routine non- & 4.1 & 71.1 & 0.6 & 0.8 & 10.0 & 11.1 & 2.3 \\
manual & 7.0 & 75.3 & 33.3 & 6.7 & 8.6 & 9.4 & 6.6 \\
Skilled manual & 1.4 & 5.0 & 0.1 & 1.2 & 76.6 & 11.8 & 3.8 \\
& 2.1 & 4.6 & 5.6 & 8.4 & 57.4 & 8.7 & 9.7 \\
Un- and & 0.5 & 6.4 & 0.8 & 3.7 & 17.2 & 62.5 & 9.0 \\
semiskilled & 1.0 & 9.1 & 55.6 & 40.3 & 20.1 & 71.4 & 35.6 \\
Agricult. & 0.9 & 2.8 & 0.0 & 14.8 & 9.4 & 24.5 & 47.5 \\
workers & 0.5 & 1.0 & 0.0 & 39.5 & 2.7 & 6.8 & 45.6 \\
\hline
\end{tabular}

Source: Survey of the socio-class structure 1984.

Note: In the first row are row percentages, in the second row are column percentages.

TABLE 1.2b

CURRENT CLASS POSITION OF RESPONDENT ACCORDING TO HIS/HER FATHER'S CLASS POSITION (per cent)

\begin{tabular}{lrrrrrrr}
\hline $\begin{array}{l}\text { Father/ } \\
\text { Current }\end{array}$ & $\begin{array}{c}\text { Profes- } \\
\text { sionals }\end{array}$ & $\begin{array}{c}\text { Routine } \\
\text { non- } \\
\text { manual }\end{array}$ & $\begin{array}{c}\text { Inde- } \\
\text { pendent }\end{array}$ & $\begin{array}{c}\text { Private } \\
\text { farmers }\end{array}$ & $\begin{array}{c}\text { Skilled } \\
\text { manual }\end{array}$ & $\begin{array}{c}\text { Un- and } \\
\text { semi-skilled }\end{array}$ & $\begin{array}{r}\text { Agricult. } \\
\text { workers }\end{array}$ \\
\hline Professionals & 27.1 & 18.3 & 2.5 & 4.1 & 16.6 & 24.5 & 6.9 \\
& 51.3 & 31.9 & 14.3 & 8.6 & 18.3 & 12.1 & 11.1 \\
Routine & 10.8 & 12.6 & 3.4 & 5.8 & 21.1 & 36.9 & 9.3 \\
non-manual & 25.1 & 26.8 & 23.6 & 15.0 & 28.3 & 22.2 & 18.3 \\
Skilled manual & 6.3 & 10.5 & 3.4 & 5.8 & 20.9 & 41.8 & 11.2 \\
& 12.5 & 19.3 & 20.0 & 12.8 & 24.2 & 21.7 & 19.1 \\
Un- and & 3.2 & 6.5 & 3.8 & 12.6 & 13.7 & 47.3 & 12.9 \\
semiskilled & 9.9 & 18.6 & 35.0 & 43.3 & 24.6 & 38.2 & 34.2 \\
Agricult. & 1.6 & 4.8 & 3.2 & 24.0 & 10.3 & 29.2 & 26.9 \\
workers & 1.2 & 3.3 & 7.1 & 20.1 & 4.5 & 5.7 & 17.3 \\
\hline
\end{tabular}

Source: Survey on socio-class structure 1984.

Note: In the first row are row percentages, in the second row are column percentages. 
TABLE 1.3

EARNINGS AND HOUSEHOLDS INCOMES (QUANTILE CHARACTERISTICS IN PER CENT OF MEDIAN)

\begin{tabular}{lrrrrrr}
\hline Characteristic & 1970 & $1975 / 76$ & $1980 / 81$ & $1988 / 89$ & $1992 / 93$ & $1996 / 97$ \\
\hline Earnings: & & & & & & \\
P10 & 62.7 & 64.2 & 63.9 & 62.1 & 56.9 & 58.7 \\
P25 & 78.1 & 76.4 & 78.6 & 75.9 & 73.4 & 77.6 \\
P75 & 124.2 & 124.1 & 127.7 & 126.1 & 136.5 & 128.2 \\
P90 & 154.1 & 151.6 & 155.5 & 152.0 & 181.5 & 170.0 \\
P90/P10 & 2.46 & 2.36 & 2.43 & 2.45 & 3.19 & 2.90 \\
Gini coefficient & 0.20 & 0.20 & 0.20 & 0.20 & 0.25 & 0.24 \\
\hline Household income per capita: & & & & & \\
P10 & 56.7 & 62.1 & 63.4 & 66.8 & 66.0 & 60.9 \\
P25 & 75.8 & 78.3 & 79.5 & 81.1 & 82.7 & 78.6 \\
P75 & 128.0 & 128.2 & 128.6 & 128.7 & 127.7 & 131.8 \\
P90 & 161.4 & 161.5 & 162.9 & 162.4 & 167.5 & 177.1 \\
P90/P10 & 2.85 & 2.60 & 186.8 & 2.43 & 2.51 & 2.91 \\
Gini coefficient & 0.22 & 0.21 & 0.21 & 0.20 & 0.23 & 0.26 \\
\hline
\end{tabular}

Sources: Atkinson and Micklewright 1992 (up to 1980); Wage surveys 1989, 1993 and 1997; Microcensus 1988, 1992 and 1996.

Note: $\quad$ Former Czechoslovakia up to 1980, the Czech Republic since 1989.

There is a break in method of collecting wage surveys between 1993 and 1997.

Nevertheless, behind the stability in the overall earnings distribution, important changes occurred in the relative positions of different groups. In the analysis of earnings variance based on the data from statistical income surveys and social stratification surveys, three major developments in wage inequality were identified after 1970, mostly continuing from late 1950s (Večerník 1991). All of these changes can be considered in consonance with the 'logic' of the communist regime and the full control it exerted over the economy and population.

First, the peak of the age curve gradually shifted in favour of older employees, as a 'founding generation' of communism maintained the advantages it had gained over its lifetime. Second, the relative wages of those in the 'productive sector' (manufacturing, construction and transport) improved continuously, while the position of the service branches (commerce, education, banking and other services) deteriorated. Third, the relative position of university-educated people declined and differences between various levels of education gradually narrowed. ${ }^{4}$

4 Educational differentials in former Czechoslovakia were kept low, even in comparison to the other communist countries. 
The system continued to be ruled by the 'need principle' which means the primary focus on the basic needs for the reproduction of society and understood mainly as individual and uniform persons ('soldiers of work'). ${ }^{5}$ Due to this, inequality of per capita income was compressed, following assumptions that people had about more or less equal needs. By contrast, inequality of total household income remained considerable, given the gap between the average wage and pension, and especially given the primary dependence of household income on the number of active earners. Both effects caused an extreme range of household income between single pensioners at the bottom and families with multiple earners at the top of income distribution.

An analysis conducted in early 1989 confirmed that if Czech society was functionally stratified in some degree in 1967 (according to Machonin 1969), it was certainly destratified in the 1970s and 1980s. The system displayed broken links between earnings, education and assets, and no data allowed the rejection of the hypothesis that the majority of the population was one rather homogeneous category completed by several distinct, but marginal groups. The debate was only about whether the period after 1968 represented a continuation of the same trajectory (only obscured at the time) or a return back to forced homogeneity. In any case, education produced marked social disparities but more by its cultural than labour market potential (Boguszak et al. 1990).

\subsection{Poverty}

Officially, there was neither richness, nor poverty under the communist system. Poverty was alleviated thanks to the system of social security that covered the whole population from the late 1960s. The very reason for the small incidence of relative poverty was, however, low income inequality. The narrow range of income distribution created a situation in which the bottom sector of the population was not too far from the average. By impoverishing the population as a whole in absolute terms, the communist regime succeeded in camouflaging individual poverty in relative terms. In terms of starvation and lack of shelter, there was indeed little poverty in Czechoslovakia. Due to the continuing pre-war social democratic traditions and relatively good performance of the economy, but also due to its great efforts outside the formal economy, the Czech populace succeeded in maintaining a decent standard of living.

This does not mean, however, that poverty in absolute terms was entirely eliminated. Extremely low pension benefits allotted to the members of the former bourgeoisie and expropriated peasants were used as weapons in the 'class war' of the 1950s and early 1960s. Due to the absence of any valorization or indexing, the purchasing power of older people's pensions dropped below the average pension and the average pension

5 This principle was explicitly formulated by Marx as the prominent mechanism of the rewarding (and exploitation) of hired labour by capitalists: they do not pay for the labour itself but for the reproduction of the labour force. Wrongly ascribed to capitalism, this principle was tacitly accomplished by 'real socialism'. Conversely, the 'market principle' is understood as the assertion of links between labour performance and results with rewards and incomes (Večerník 1999b). 
dropped behind the average wage. 6 The living conditions of single women with children were also very acute. Since the early $1980 \mathrm{~s}$, the 'line of social neediness' served as an orientation base for local authorities to administer means-tested social benefits. However, no exact rationale was given by government authorities for the amounts of money to be given to households in need. And no statistical information on the number of households and the proportion of the 'officially poor' was ever published.

Unlike Hungary and Poland, where important changes occurred from the 1970s, former Czechoslovakia returned after the bloody experience of the 1968 Prague Spring to the path of rigid communism. No deviation from the hard-line in terms of allowing small business, better motivating skilled people or partially opening borders or information channels was accepted. Consumer choice in textiles and durable goods continued to be achieved only through special shops (accepting only foreign currency) or smuggling from the West. Even the Soviet 'perestroika' was regarded with suspicion by the Czech nomenclatura, stressing this time (contrary to the communist vocabulary since 1948) that 'we have our own way'.

The communist world of stagnation was also a framework of stability in terms of full employment and decent welfare. People appreciated it little, being accustomed to and disgusted by the propaganda that perpetually stressed these features in contrast to the capitalist world of unemployment and poverty. Satisfaction with the regime decreased even according to polls of the time (the respondents of which could not be sure that their answers would not be used against them in some way). According to confidential surveys at the time, in 197049 per cent of respondents saw their standards of living improve over the previous five years, followed by 44 per cent in 1985 and 38 per cent in 1989 , the outlook for the next five years being perceived optimistically by 38 per cent in 1970, 34 per cent in 1985 and 32 per cent in 1989 (Opinions of citizen 1989). ${ }^{7}$

Despite growing dissatisfaction with material well-being and cultural closeness, the regime maintained its support especially among workers of privileged branches and cooperative farmers. Special policies in distribution scarce goods (better meat and fruit, imported textile and durable goods) were adopted to prefer 'working class' localities and regions. On a much larger scale, transfers went from the Czech lands to Slovakia. Despite decreasing economic efficiency, sections of the population advantaged by the regime and, therefore, supportive to it were still large enough to guarantee it longer survival. It was more especially external pressure which triggered the activation of a part of the population which started a snowball movement leading eventually to the implosion of the system.

6 Pension and other benefits were increased from time to time according to government decisions or new laws. The increase was presented as a 'gift' from the party/state. The retirement pension dropped from 51 per cent of the average gross wage in 1960 to 41 per cent in 1975, then started to increase slowly again.

7 The Institute of Public Opinion was re-established in the early 1980s. Officially, it formed part of the Federal Statistical Office but in reality, it functioned as an observatory for the Politburo of the Communist Party, in monitoring the public climate. Only very few of the results it produced were made public. 


\section{SOCIAL CLASSES AND INCOMES IN THE TRANSITION PROCESS}

\subsection{Economic, social and political reforms}

The transformation, which started in former Czechoslovakia in 1990 after the implosion of the communist regime, involved the introduction of the democratic political regime and thorough reform of the economic and social system. The starting point was depriving the communist party of its 'leading role' (formally incorporated in the Constitution) in politics and the economy in order to make possible all processes of liberalization. The former political elite disappeared, its top members going mostly into retirement, the lower sections into business. Most members discarded their membership card which had ceased to be a 'work permit' for important functions. Loyal, mostly older communists remained organized with the Communist Party which has still the largest membership. 8

The political system was established on a new, democratic base. The original anticommunist movement Civic Forum was transformed into political parties of which the Civic Democratic Party of Vaclav Klaus dominated the political scene in the period of 1992-97. Both parties surviving from the past (the Communists and the Christian Democrats) and the new parties (among them especially Civic Democratic Alliance and the Czechoslovak Social-Democratic Party) started to shape political life and channel attitudes of the population. The transformation of the political system was accompanied by the Slovak drive for independence which finally led to the split of Czechoslovakia into two separate states in 1993.

Economic reform launched price liberalization and the privatization of the land, houses and all means of production. Along with restitutions and 'standard methods' of privatization (auctions and purchase), coupon privatization was launched, in which vouchers were given to 6 millions adult Czechs. This method was supposed to be just (because the property was distributed to the whole population), quick (no search for investors was needed) and capitalist (a lesson in investment for all people). However, as unexpectedly numerous and energetic investment privatization funds entered the scene, the ownership of this property quickly became concentrated along with transfer of capital to unknown hands. Privatization is still in the process, the biggest banks being on the agenda for 1999 .

8 Although the Communist Party kept only about one tenth of its previous members, with 160,000 members it is still far the largest political party, in comparison with the largest new parties - the Civic Democratic Party with 22,000 members and Social Democrats with 14,000. 


\subsection{New labour market model}

Consequently, administration of labour was removed and the labour market has reappeared with its opportunities and risks. However, the expectations of the populations in the early 1990s seemed gloomier than the subsequent reality. Due to the huge absorption capacity of the tertiary sector, self-employment and the departure of pensioners from the labour force, unemployment remained low in the Czech economy up until the mid-1990s. This is also due to the failure of firms to restructure. Because of the cross-ownership of former state enterprises (owned by investment funds, in turn owned by the bank giants, which were themselves owned by the state), little or no pressure on increased productivity was exerted and labour was continuously hoarded for an unpredictable future. ${ }^{9}$

In the former state sector, wage regulation was maintained for some time. ${ }^{10}$ In contrast, new and foreign firms had considerably greater liberty in wage settings, with many of them seeking to attract highly qualified people by offering much better rewards. Labour mobility increased as individuals found better paid jobs, created private firms or sought work abroad. It introduced marked movements in the sources and extent of earnings inequality, created the conditions necessary for improving returns to education, providing better work incentives and gradually adjusting the reward system to that in the West. After the price shock and labour shrinking of 1990-91, wages started to rise more rapidly than productivity of labour.

Provoked by the changes in the labour market, it was necessary to put in place certain social measures from the very beginning of the transformation: introduction of unemployment benefits, the valorization of pensions and other benefits, the fixing of the guaranteed minimum wage and the establishment of the state poverty line - the living minimum (the minimum subsistence income). More consistent changes of the social system began after 1995. This move was proclaimed a shift away from the paternalistic state towards an efficient and targeted welfare policy, and strengthening the responsibility of individuals and families. On the whole, the social reform was in the end less radical than anticipated. The transformation of the social security system was developed in three fields:

9 According to the OECD study, there were three main factors contributing to the Czech 'employment miracle': labour supply reductions, wage moderation and good initial conditions 'in terms of the industrial structure of employment and the skill levels of the workforce'. On the other hand, explanations such as the slow pace of structural change, unrecorded employment or hidden migration have been rejected as of minor importance while the role of labour market policies was stressed as highly positive (Review 1995: 132f).

10 After no wage control whatsoever at the beginning of 1993, a tax-based wage regulation - to be removed upon completion of the large-scale vouchers privatization - was re-introduced. Wage regulation was definitively abolished in mid-1995. The abolition was welcomed both by liberals (more market) and unions (more freedom for wage rises) alike. 
Within the social insurance, the regulation of pension insurance had to take into account the deteriorating dependency ratio. This was the reason for a new scheme which accepted a gradual rise in the retirement age. ${ }^{11}$ The government is obliged to valorize pensions against inflation (in each case of price increases of 5 per cent or more) and real wage rises (by at least one third of this rise).

Within state social support, several family benefits were combined by the new system, significantly complemented by new benefits and income-testing. The living minimum serves as a dual testing basis: indeed, it serves as (a) an income threshold (by multiples) where benefit is withdrawn and (b) as the amount of money from which the benefit is calculated.

Social assistance is oriented towards households with incomes below the living minimum and is conceived at the maximum possible decentralization of decisionmaking on benefit entitlements. The regulation and administration of social assistance has to ensure better targeting and means-testing.

Complementary private schemes should encourage people to take more responsibility for their current and future situation. Since 1993, additional pension insurance has enabled citizens to insure themselves with commercial insurance companies, this with the help of a state contribution. For this purpose, pension funds are established as stock companies. ${ }^{12}$

\subsection{Budgetary policy}

The withdrawal of the state from economic and social life is indicated by the share of the state budget in the national product. Whereas in 1989, the share of public expenditures in GDP represented 72 per cent, it sank below 50 per cent in 1995 and continued to decrease slowly by about one per cent per year until 1997. Public debt was much lower in the Czech Republic already before 1989 and the country maintained its specific position among CEE countries by very restrictive policy aimed at avoiding a budgetary deficit. ${ }^{13}$ However, the yields from privatization as well as a surplus of pension contributions bill were largely used by the state to cover other expenses. The picture was eased by the fact that 'bad debts' (both of the former and current regime) were kept separately in newly created institutions.

\footnotetext{
11 The pension age was to be gradually increased from the current 60 years for men and 53-57 for women (according to the number of children) up to 62 for men and 57-61 for women by 2006.

12 Currently, only about 11 per cent of workers have taken out private insurance. According to some estimations, only 50 per cent of workers will acquire it in the long-run, due to the lack of family finances.

13 The first deficit was planned in the 1999 state budget, which was passed by Parliament with the help of the Communists and Christian Democrats. However, a couple of days after the approval has appeared that planned revenues had been overestimated by the Ministry of Finance and the probable deficit will be much higher than expected.
} 
Seeking macroeconomic stabilization, two 'cushions' were created: (1) a monetary cushion, in which Czech currency was heavily undervalued against the purchasing power parity (e.g. ERDI against the German Mark increased from 3.1 in 1989 to 4.5 in 1991); (2) a wage cushion in which real wages were squeezed in relation to the productivity of labour, by which unit labour costs sank from 64 per cent in 1989 to 48 per cent in 1992. While the first cushion is still in function, the other was largely removed by rapid wage increase advancing growth in the productivity of labour (Fassman 1997). As the competitiveness of the Czech economy did not improve, negative payments and the trade balance (which the Czech National Bank tried to counter-balance by even tighter monetary restriction) led to an economic recession in the late 1990s.

\subsection{The growth of the private sector of the economy}

Privatizations and creation of de novo private firms changed the composition of the labour force according to sector of ownership completely. Whereas in 1989, only 1.3 per cent of workers were employed in the private sector, this percentage increased to 31.1 in 1992 and to 58.9 in 1996; in 1996, another 14.4 per cent of workers were employed in the mixed sector. The statistical indicator of 'workers according to type of management' was replaced in 1997 by 'employees by sector', according to which 66 per cent of employees worked in the private and 34 per cent in the public sector. While 1.8 million employees (out of a total 3.4 million) worked in non-financial private national firms, 0.2 worked in non-financial private firms under foreign control (Statistical Yearbooks).

Despite the successful completion of the main privatization steps, the whole process cannot be considered finished. The withdrawal of the state from the economy was largely nominal: 'The state still remains the core investor in the major financial institutions that founded the largest privatization funds ... The state remains the greatest creditor of many large and medium-sized enterprises ... Many companies are thus private in name only' (Mlcoch 1995: 155). The interim result is, then, a 'recombinant property' with the government's central role as a core investor indirectly controlling the most important banks and, through them, the most important enterprises (Stark 1992). The Social-Democratic government in power since mid-1998 is searching for a way how to revitalize the core firms of Czech manufacturing industry.

\subsection{Informalization and demonetization}

In the transformation period, the informal economy expands due to free private business, open borders and a temporarily weak legal framework. In the Czech Republic, the informal economy is not as large as in other transitory economies: its share in GDP is estimated at 10-15 per cent. A very frequent form is avoiding taxes and employment regulations by small entrepreneurs (which is paralleled by large firms not paying social contributions). Since 1989, Czech society has seen a lot of scandals concerning tax fraud, some of them provoked by the huge difference between two VAT rates (22 per cent for the majority of goods, 5 per cent for services including heating), applied sometimes to the same provisions but treated differently. In trade, especially markets of 
Vietnamese immigrants providing cheap smuggled textile goods are everywhere and welcomed by most of the population.

Coping strategies of households are based mainly on a monetary base - labour mobility, secondary jobs, the use of savings. Freedom in business licenses is largely used by employees who sell the same skills outside their main job and often also in the same working time. Surprisingly, earning some extra money is perceived by only a minority of people as a necessity and the tendency towards this opinion is rather decreasing from one-third of the population in 1990 to only one-fifth in early 1998. A slight decreasing trend is also observed in do-it-yourself strategy (EEA surveys). Together with the decreasing agricultural population and relatively favourable prices of food, fewer people produce food for their own households than under the communist regime. No significant demonetization of the Czech economy is appearing.

\subsection{The rise in income inequality}

Transformation of the economic and social system brought about considerable movements in previously static income disparities. Some of the measures adopted have had equalizing effects: the introduction of the minimum wage (which was, however, frozen for many years), legal establishment of the living minimum (previously existing only as a recommendation for social administration) and valorization criteria for pensions. But the main movements have led to greater variation in all individual sources of income except pension benefits. This process has resulted in rising inequality of household income.

In our observation of income inequality, indicators of income per household and per capita are distinguished. Statistical income surveys show that the rise has been slower in income per household income and faster in per capita income (Table 2.1). The changing pattern of distribution is indicated by correlation coefficients. While the correlation between income per household and the number of active earners as well as between per capita income and dependent children is weakening, the correlation between the two indicators of income is strengthening. This indicates that disparities in market income are becoming wide enough to prevail over a family's participation in the labour market: even households with a lesser number of active earners have the chance to prosper. ${ }^{14}$

Disparity between shifts in distribution of income per household and per capita is explained by the changing composition of households. While the average size of households in the period 1988-96 remained the same (2.66 members) and the number of dependent children decreased slightly (from 0.76 to 0.69 ), the number of economically active members decreased considerably (from 1.48 to 1.24 ). Two opposite effects have contributed to this result: the pushing of working pensioners to leave the labour force (by heavily taxing earnings taken in parallel with pension benefit) and a

14 According to the same source, coefficient Gini of wages of all economically active workers rose from 0.19 in 1988 to 0.24 in 1996. 
TABLE 2.1

CHARACTERISTICS OF DISTRIBUTION OF HOUSEHOLD INCOME

\begin{tabular}{lcccccc}
\hline Indicator & \multicolumn{3}{c}{ Per household } & \multicolumn{3}{c}{ Per capita } \\
\cline { 2 - 7 } & 1988 & 1992 & 1996 & 1988 & 1992 & 1996 \\
\hline Coefficients and decile ratio: & & & & & & \\
Variation & 0.53 & 0.69 & 0.73 & 0.40 & 0.56 & 0.65 \\
Gini & 0.29 & 0.32 & 0.33 & 0.20 & 0.23 & 0.26 \\
Decile ratio (D90/D10) & 5.12 & 4.95 & 5.21 & 2.43 & 2.51 & 2.91 \\
\hline Correlations (Pearson coefficients): & & & & & \\
Size of household & 0.59 & 0.55 & 0.52 & -0.64 & -0.51 & -0.15 \\
Number of active earners & 0.73 & 0.59 & 0.61 & 0.04 & 0.10 & 0.18 \\
Number of children & 0.29 & 0.28 & 0.28 & -0.75 & -0.59 & -0.21 \\
\hline
\end{tabular}

Sources: Microcensus 1988, 1992 and 1996.

Notes: Income per capita is weighted by persons.

Correlations are computed on households as observation unit.

All coefficients are significant at the level $<0.001$.

pulling of women, who can be supported by their better-paid husbands to stay at home and/or support them in the family business. ${ }^{15}$

Table 2.2 shows income distribution by decile shares. According to income per household, the bottom share increased slightly and the top share rose considerably. According to income per capita, the top share rose too but the other categories behaved differently in the two periods. Between 1988 and 1992, the relative position of the lower half of the income distribution was largely maintained while the upper half appeared to have lost. This was the pre-privatization period of the social-liberal government which maintained universal social benefits and kept wages under control. Between 1992 and 1996, relative stability or increase was rather registered in the upper half while the lower half lost. This was the privatization period of the self-proclaimed liberal government which replaced universal benefits with targeted ones, removed wage regulation, froze the minimum wage and finally allowed a rapid rise in earnings not endorsed by the growth of productivity of labour. In both periods, the middle of the income distribution was squeezed.

15 The share of households with a sole active earner increased from 29.7 to 36.7 per cent and the average of economically active members in those households has decreased from 1.86 to 1.82 between 1988 and 1996. 
TABLE 2.2

DISTRIBUTION OF HOUSEHOLD INCOME ACCORDING TO DECILE SHARES AND REAL GROWTH (per cent)

\begin{tabular}{lrrrrrrrr}
\hline \multirow{2}{*}{$\begin{array}{l}\text { Decile } \\
\text { share }\end{array}$} & \multicolumn{3}{c}{ Per household $(\mathrm{HH})$} & \multicolumn{3}{c}{ Per capita (PC) } & \multicolumn{2}{c}{ Real growth in 1988-96 } \\
\cline { 2 - 9 } & 1988 & 1992 & 1996 & 1988 & 1992 & 1996 & HH & PC \\
\hline 1 & 2.5 & 2.9 & 2.8 & 5.3 & 4.9 & 4.3 & 105.6 & 74.6 \\
2 & 4.1 & 4.1 & 3.9 & 6.6 & 6.4 & 5.9 & 88.5 & 82.8 \\
3 & 5.9 & 5.8 & 5.6 & 7.4 & 7.3 & 6.8 & 88.7 & 85.9 \\
4 & 7.6 & 6.9 & 6.7 & 8.1 & 7.9 & 7.6 & 81.7 & 87.7 \\
5 & 9.3 & 8.1 & 7.9 & 8.8 & 8.6 & 8.3 & 79.7 & 88.5 \\
6 & 10.7 & 9.6 & 9.4 & 9.6 & 9.2 & 9.1 & 81.4 & 88.6 \\
7 & 12.0 & 11.1 & 10.9 & 10.6 & 10.1 & 10.1 & 84.5 & 89.2 \\
8 & 13.2 & 12.8 & 12.7 & 11.8 & 11.3 & 11.5 & 88.9 & 90.8 \\
9 & 15.1 & 15.2 & 15.4 & 13.6 & 13.2 & 13.7 & 95.0 & 93.7 \\
10 & 19.6 & 23.5 & 24.7 & 18.2 & 21.1 & 22.6 & 117.3 & 116.1 \\
Total & 100.0 & 100.0 & 100.0 & 100.0 & 100.0 & 100.0 & 93.4 & 93.4 \\
\hline
\end{tabular}

Sources: Microcensus 1988, 1992 and 1996.

Notes: Income per capita is weighted by persons.

In terms of real income per household it means that while the lowest and highest income categories have increased their standards, middle incomes lost 10-20 per cent of their purchasing power. However, the real rise of the bottom decile share is rather spurious because there was a considerable demographic mobility within it. In terms of income per capita, only the top decile share gained and the bottom decile share lost the most. Results given by the two income indicators are disproportionate which informs us about the uneven change in various categories of the population and the reconstruction of the income hierarchy in demographic and sociological terms. The most apparent change was the replacement of pensioners by children in the lower part of income distribution. In other words, the lowest income ceased to be represented solely by transfer income (pensioners $=$ non-working poor $=$ old poverty) and is newly represented by low market income $($ families with children $=$ working poor $=$ new poverty $)$.

In Table 2.3, we estimate the relative weight of two sets of income predictors: (1) demographic or life-cycle variables (age, the size and composition of households) and (2) economic or labour market variables (education and type of occupation). We observe a considerable weakening of the life-cycle profile of household income in favour of its occupation profile. According to income per household, specific importance of age of the household's head approaches zero and the weight of the number of children tends to disappear, especially following the diminishing relation of family allowances to their earnings. According to income per capita, the specific weight of the number of children 
TABLE 2.3

ANALYSIS OF VARIANCE OF (LN) HOUSEHOLD INCOME (PER CENT OF TOTAL VARIANCE)

\begin{tabular}{lcrrrr}
\hline \multirow{2}{*}{ Factor } & \multirow{2}{*}{ No. of categories } & \multicolumn{2}{c}{ Per household } & \multicolumn{2}{c}{ Per capita } \\
\cline { 3 - 6 } & & 1988 & 1996 & 1988 & 1996 \\
\hline Main effects & & 62.82 & 43.73 & 59.26 & 48.22 \\
No. of active earners & 3 & 24.21 & 27.86 & 3.84 & 3.92 \\
No. of children & 5 & 5.42 & 2.40 & 31.84 & 19.43 \\
Age of the & 7 & 1.89 & 0.23 & 3.03 & 0.22 \\
household head & 2 & & & & \\
Non-manual & 4 & 3.29 & 3.45 & 1.19 & 3.59 \\
Education & 3 & 0.08 & 0.18 & 0.07 & 0.64 \\
Locality & & 3.16 & 2.36 & 2.60 & 1.75 \\
2-ways interactions & & 65.98 & 46.08 & 61.86 & 49.97 \\
Explained & & & & & \\
\hline
\end{tabular}

Sources: Microcensus 1988 and 1996.

Notes: Only households with head in prime age (25-54) included. Income per capita is weighted by persons.

All coefficients are significant at the level $<0.001$.

more than halved. In another words, while in 1988 the number of children itself explained 46 per cent of the variance of income per capita in households in the prime age, this percentage was 27 per cent in 1996 (the decrease was less impressive for all households which was 25 and 20 per cent respectively).

From the other side, the importance of labour market characteristics of individuals (household heads) has increased. The manual/non-manual distinction, not distinguishable in the communist period, re-appeared in both income indicators. The estimated contribution of education towards income levels per capita increased three times. All those changes indicate that there was a considerable social mobility in income hierarchy, concretely speaking that non-manual and educated workers went up while manual and less skilled people went down. There were also other important changes according to branch and sector of ownership but unfortunately the available data do not allow us to make a comparison over time.

\subsection{Redistribution of income}

The communist society was endlessly redistributive. As almost all of the gross national product ran through the state budget, all yields and losses were put into one pot and nobody ever learned how much was taken or given to whom and for what. After 1989, 
income distribution was made more transparent in several steps. The first step was the abolition of price subsidies (through a negative turnover tax) in mid-1990. The second step was unification of different kinds of income tax into one, paid by all self-employed since 1991. However, the most important steps were effected by 1993 when the (almost flat at the time) wage tax was replaced by a new universal income tax, the turnover tax was replaced by a value added tax, and a new system of employee and employers pension and health contributions was introduced.

If we take the population as a whole, the rise in the financial burden of households is apparent: according to income surveys of 1988 and 1996, direct taxes and contributions of households rose from 13 to 17 per cent of their gross income while transfer income rose from only 25 to 26 per cent of their net income. Regarding change in distribution over time, we can compare only non-farm employee households (Table 2.4). ${ }^{16}$ Both taxes and social benefits are distributed more steeply among households, following the reform design. The progressiveness of the new system appears despite the fact that the majority of the active population were still hit only by the first band of income tax (15 per cent) and only very few by the second (20 per cent). Regarding social benefits, their targeting was the main purpose framed by the new system of state social support introduced in 1996.

TABLE 2.4

RELATIVE TAXES AND SOCIAL BENEFITS ACCORDING TO DECILE SHARES (per cent)

\begin{tabular}{lcccccccc}
\hline \multirow{2}{*}{$\begin{array}{l}\text { Decile } \\
\text { share }\end{array}$} & \multicolumn{3}{c}{ According to income per household } & \multicolumn{3}{c}{ According to income per capita } \\
\cline { 2 - 9 } & \multicolumn{3}{c}{ Taxes } & \multicolumn{3}{c}{ Social benefits } & \multicolumn{3}{c}{ Taxes } & \multicolumn{3}{c}{ Social benefits } \\
\cline { 2 - 9 } & 1988 & 1996 & 1988 & 1996 & 1988 & 1996 & 1988 & 1996 \\
\hline 1 & 16.1 & 16.6 & 17.0 & 17.9 & 10.3 & 11.9 & 30.1 & 30.5 \\
2 & 14.1 & 16.0 & 23.4 & 22.0 & 11.9 & 14.8 & 24.0 & 22.0 \\
3 & 13.6 & 16.3 & 24.2 & 21.8 & 13.0 & 16.4 & 20.4 & 17.6 \\
4 & 14.4 & 17.2 & 21.2 & 18.3 & 13.7 & 17.4 & 18.0 & 15.5 \\
5 & 14.9 & 18.0 & 18.5 & 15.4 & 14.1 & 18.3 & 16.6 & 14.1 \\
6 & 15.2 & 18.2 & 16.6 & 13.6 & 14.8 & 18.8 & 15.3 & 13.8 \\
7 & 15.3 & 19.7 & 15.6 & 11.2 & 15.4 & 19.8 & 14.4 & 11.7 \\
8 & 15.7 & 20.2 & 14.7 & 9.9 & 16.0 & 20.4 & 14.2 & 10.1 \\
9 & 16.0 & 21.4 & 13.8 & 7.8 & 17.2 & 21.6 & 14.1 & 7.8 \\
10 & 16.1 & 24.1 & 12.4 & 4.8 & 17.4 & 24.6 & 15.4 & 4.4 \\
Total & 15.3 & 20.0 & 16.7 & 11.9 & 15.3 & 20.0 & 16.7 & 11.9 \\
\hline
\end{tabular}

Sources: Microcensus 1988 and 1996.

Notes: Only households of non-farm employees included.

Income per capita is weighted by persons.

Relative tax is computed as percentage of income tax and social contributions in gross household income. Relative social benefits are computed as percentage of social benefits in net household income.

\footnotetext{
16 Under the communist regime, taxes paid by households of self-employed (almost absent anyway) were not registered in income survey. Cooperative peasants were exempted from direct taxes.
} 
Shifts registered by income surveys document changes in the system. Generally speaking, Czech society is moving from redistribution based on family life-cycle to redistribution based on family labour market participation - its extent (the number of active earners) as well as intensity (relative earnings). The communist system of redistribution was mostly shaped following the logic of basic needs and reproduction, indicated clearly by the number of children. The new system appears to be determined differently, addressing the economic (labour market) capacity of a household. However, the effect of life-cycle surface if we take into account the entire population including pensioners: redistribution by age cohorts is even much more striking in 1996 than in 1988. This is shown by a growing gap between the average earnings and pension benefits which developed from 1992 onwards. 


\section{EMERGING NEW SOCIAL STRATIFICATION}

The transformation started to reshape the social structure of the population in several ways. First, it allowed the appearance of the old differences, bringing them back into the external sphere of formal income and conspicuous wealth. Second, it created new sources of disparities, especially through privatization and the functioning of market forces. On the one hand, besides honest entrepreneurship, black markets expanded and speculation flourished using the transformation intermezzo of lack of legislation and the insufficient performance of controlling bodies. On the other hand, besides unemployment and other sources of 'deserved' poverty, also lack of a work ethic, disinterest and crime increased when totalitarian repression disappeared. All those changes contribute to a considerable restructuring of the social stratification as a whole.

\subsection{Determinants of social stratification}

During transformation, markets open and invite all people to redefine their class position. Simultaneously, channels of mobility enlarge and make various types of motion possible. Consequently, the hierarchy of prestige changes and the lifestyle of people develops in response to the Western challenge. By this, all directions of stratificational change in various Weberian meanings advance. ${ }^{17}$ However, in transforming countries, the stratification is more obscure than in traditional capitalist countries. If we propose a more comprehensive delineation in the Weberian sense, we should observe not only changes in occupation, but also material conditions of life, associative links and people's opinions.

Not only the market scene and corresponding labour effort are in play. Because no new society is created, it is only the old that is reshaped, previously established networks of 'old comrades' are still in function. They hold important economic information and personal contacts, which eased the way for them to take over a large part of national property. ${ }^{18}$ But also new networks were established almost overnight, mobilized by the extraordinary opportunity to take a 'more than equal' part in the privatization process. In them, the old and new local elites have been mixed, combining in this way the misuse of information and real access to property with their 'democratic' legitimization.

Lack of rules in a transitory situation led to the expansion of rent-seeking behaviour and its growing success. Instead of market forces, corporatist negotiations or settings

17 Max Weber distinguishes earnings class (Erwerbsklasse) by their market power, 'social class' (Soziale Klasse) by an easy intra- and intergenerational mobility and 'status group' (Stand) by lifestyle and prestige which is anyway very close to social class (Weber 1956: 223-227).

18 No especial effort was made by the post-1989 government to transfer all property owned or administered by the former Communist Party of Czechoslovakia. According to some opinions, the real property 2-3 times larger than documented, all of which disappeared to the hands of former functionaries (daily Lidove Noviny 19.3.1999). 
prevailed in establishing important prices (such as meat or fuel), wages (of entire sectors under union control as well as of important professions under chamber control such as lawyers) and access to some occupations. The state remained active in wage control here (up until 1993), the control of rents of former state apartments (about a third of all housing) and other prices (public transport). Not only the activity, but also the inactivity of the state matters: because in the actual system, creditors are disadvantaged against indebtors, and misuse of credit (bank or business) became a special field of rent-seeking.

It is not possible to find documentation about how much individual forces function. In this area, no statistics exist. We can only ask people how they perceive the system, more concretely, what are sources of life success in their view (Table 3.1). According to attitudinal surveys, in the first place is individual effort and hard work and in the second place 'social capital', especially useful acquaintances. In the third place comes social background and in the last place ascriptive characteristics. While up until 1997, the importance of all factors was increasing, it was again decreasing after 1997. This might be connected with a smoother interface between liberalism and socialism after the 1997 elections. Despite the fact that the opinion on market roots of individual success increased in the transformation period, it did not become dominant.

TABLE 3.1

OPINIONS ABOUT FACTORS OF LIFE SUCCESS (INDEX)

\begin{tabular}{lcccccc}
\hline \multicolumn{1}{c}{ Factor } & 1992 & 1997 & 1999 & $\begin{array}{r}\text { Difference } \\
1997-92\end{array}$ & $\begin{array}{r}\text { Difference } \\
1999-97\end{array}$ & $\begin{array}{r}\text { Difference } \\
1999-92\end{array}$ \\
\hline Rich background & 36.8 & 49.1 & 39.3 & 12.3 & -9.8 & 2.5 \\
Educated parents & 30.4 & 41.8 & 36.1 & 11.4 & -5.7 & 5.7 \\
Higher education & 48.5 & 63.9 & 54.5 & 15.4 & -9.4 & 6.0 \\
Ambitions & 70.3 & 75.2 & 72.6 & 4.9 & -2.6 & 2.3 \\
Talent & 68.6 & 71.4 & 68.3 & 2.8 & -3.1 & -0.3 \\
Hard work & 75.5 & 72.3 & 75.4 & -3.2 & 3.1 & -0.1 \\
Good contacts & 63.7 & 71.6 & 64.3 & 7.9 & -7.3 & 0.6 \\
Political connections & 31.4 & 50.1 & 38.7 & 18.7 & -11.4 & 7.3 \\
Race or ethnicity & 19.2 & 30.4 & 27.7 & 11.2 & -2.7 & 8.5 \\
Religion & 12.0 & 13.2 & 12.7 & 1.2 & -0.5 & 0.7 \\
Locality of origin & 23.5 & 20.3 & 28.7 & -3.2 & 8.4 & 5.2 \\
Gender & 26.8 & 30.5 & 28.7 & 3.7 & -1.8 & 1.9 \\
Political opinions & 34.3 & 31.3 & 29.5 & -3.0 & -1.8 & -4.8 \\
\hline
\end{tabular}

Sources: ISSP-1992, ISSP-1997, ISSP-1999.

Note: Index is constructed from 5-points scale where 100=substantial and $0=$ not important at all. 
In comparison with other reform countries, social background and political connections are considered weaker in Czech society. In this sense, it is closer to Western countries. In the West, however, much more importance is ascribed to education, be it the education of parents or - especially - the education of a person himself.

\subsection{Old and new elites}

The most apparent and immediate change occurred within the political elite which was exchanged almost completely. However, in spite of this expectation a radical break was not fulfilled. The Czech 'Velvet Revolution' nominated a top communist bureaucrat as the first Prime Minister of the new democratic government (as an example to follow) and stifled any debate about the eventual banning of the Communist Party. None of the leaders of the 'normalization' regime were ever punished, not even for inviting the Soviet occupation army to the country in 1968. The so-called Lustration Law which prohibited members of the former nomenclatura and secret police from taking up public positions, was passed against huge local opposition (and criticism from international bodies). Upon its application, the people affected easily passed from public services into the economy using their unique social networks and enriching themselves considerably, mostly to the detriment of a smooth implementation of the new economic order.

A different story concerns the economic elite - i.e. the directors of big firms (Table 3.2). Following the survey results, the recruitment mode was called a 'revolution of deputies', meaning that the majority of newcomers had occupied the position of deputy director or department manager under the previous regime: 'Thus the transition to the market appears not to have altered elite recruitment patterns so much as speeded them up'. Unlike the former state sector, there are more newcomers in managerial positions in the de novo private sector. The class origin of both sections of the economic elite was from privileged groups, the latter even more striking than the former. The same is true, however, about the political elite. To sum up, the 'elite circulation has not been accompanied by class circulation' (Hanley et al. 1998: 27).

All the evidence gathered attests to the fact that the managerial class has continued unhindered in the transition from central planning to the market system and is climbing into (if not remaining within) the upper class. Their salaries followed Western patterns even in unprosperous firms in state ownership and 'golden handshakes' are given even to the top managers of heavily failing state banks. ${ }^{19}$ Managers took considerable power and privileges without shouldering the responsibilities for their firms. The assertion that post-communism is a managerial system in which property relations are not well identified, thus resulting in a situation in which bank and fund directors become the most powerful players (Eyal et al. 1998), is in regard to Czech society certainly pertinent.

\footnotetext{
19 According to the Trexima survey of managerial earnings, the average yearly salary of a managing director was between US\$ 30,000 and US\$ 40,000 in 1997. Apparently, managers of top banks and firms were not included in the survey.
} 
TABLE 3.2

CHARACTERISTICS OF THE ECONOMIC ELITE ACCORDING TO SECTOR OF OWNERSHIP (DIRECTORS)

\begin{tabular}{lrrrr}
\hline Characteristic & State & Privatized & Private & Total \\
\hline Age: & & & & \\
$20-29$ & 1.3 & 1.2 & 6.8 & 2.1 \\
$30-39$ & 14.4 & 14.0 & 24.7 & 15.8 \\
$40-49$ & 40.6 & 45.7 & 47.9 & 44.3 \\
$50-59$ & 39.4 & 3.3 & 17.8 & 33.0 \\
60 or above & 4.4 & 5.8 & 2.7 & 4.8 \\
Tertiary major education: & & & & \\
No tertiary & 21.9 & 14.0 & 13.7 & 16.6 \\
Technical & 34.4 & 48.6 & 35.6 & 41.8 \\
Economics & 31.9 & 28.8 & 38.4 & 31.3 \\
Other & 11.9 & 8.6 & 12.3 & 10.3 \\
Ever member of the Communist Party (CP): & & & \\
Yes & 64.4 & 60.1 & 56.2 & 60.9 \\
No & 26.3 & 31.7 & 37.0 & 30.7 \\
Missing & 9.4 & 8.2 & 6.8 & 8.4 \\
Own business in 1993 & 16.3 & 19.3 & 68.5 & 25.8 \\
Father CP Member & 47.1 & 44.8 & 37.7 & 44.6 \\
Family Business & 32.1 & 35.9 & 45.9 & 36.1 \\
\hline
\end{tabular}

Source: Social Stratification in Eastern Europe after 1989 (Hanley et al. 1998).

\subsection{Middle classes}

According to a leading narrator of the current capitalist society, we distinguish here the 'old' middle class, occupied in the production and distribution of material goods and services, and the 'new' middle class, occupied in the production and distribution of symbolic knowledge (Berger 1986: 67). It turns out that whereas the old (entrepreneur) middle class was almost completely destroyed, sections of the new middle class remained 'physically', but not 'socially'. The re-establishment of the entrepreneurial middle class is much slower and more complicated than was expected, and the transformation of important sections of public employees into the intellectual middle class is marked by disintegrative disparities. This is at least a picture we recognize in Czech society.

The main mass movement launched by privatization and liberalization of the economy was the introduction of small-scale entrepreneurs to the scene. As the Czech communist regime was the most determined in its liquidation of petty bourgeoisie and never tolerated even the smallest signs of 'capitalism', grass-roots entrepreneurship saw a flourishing start from zero. However, it can hardly be termed an explosion: 6.2 per cent 
of the labour force were self-employed and 2.5 per cent were entrepreneurs at the beginning of 1993 while 9.2 per cent were self-employed and 4.2 per cent were entrepreneurs in mid-1998 (Labour Force Surveys).

According to the statistics, around 2.5 times more business licenses have been issued than corresponds to the share of self-employed people in the labour force. It means that a great deal of self-employed work is still backed by dependent employment and formally constitutes a second job. Even much larger is the percentage of licenses which are used only occasionally, if at all. Survey data tell us that of those holding a license in mid-1992, private business was the only job for 11 per cent, primary employment for 29 per cent and a supplementary source of income for 60 per cent; those figures have changed but in 1998 still only 15 per cent were exclusively engaged in private business, 37 per cent as primary employment, and 48 per cent as a supplementary source of income (EEA surveys).

In the Czech reform, there has not been much support for small private entrepreneurs and only scant recognition of the fact that all had to start from scratch. In auctions for small firms, local residents with little credit were competing with big foreign capital and often even organized attacks by speculators - this despite all the promises the state made to control such illegal operations. No tax holidays or allowances were accorded to these beginners in business and tax rates were established on a level comparable with the most redistributive Western countries. New businessmen have thus suffered from the multiple burdens of high income tax, corporate tax, and payroll tax, and low depreciation (writeoff) rates on their productive capital.

The gloomy conditions of the new entrepreneurs continues with regard to credit access and business policies. Credit access is distorted by the fact that the banking giants largely owned by the state have maintained a strong monopoly of power and have made credit expensive. In new small banks, the management could easily defraud clients of their money in circumstances of absent or only symbolic control. This resulted in many cases of bankruptcy, diminishing the credibility of small banks and further strengthening the dominant position of banking giants. As regards business policy, the liberal enthusiasm of the 'liberal' government led to an underestimation of the importance of establishing the legislative framework and building institutions to enforce it.

When compared with the rebirth of the 'old' (business) middle class, the transformation of employees in the state sector into the 'new' middle class is less visible but still in some sense easier. It is because 'physically', this class is already present but it needs to be established 'socially'. Expectations concerning the return to its previous position have been left unfulfilled as wage statistics witnesses: the rise of financial sector and public administration contrast with the stagnation of education and health services (Table 3.3). Hence the new situation has affected the various categories to varying degrees and it is necessary at least to distinguish between state bureaucracy, banking and public services.

Bureaucracy of all kinds was kept and cherished by the communist regime. After November 1989, it transferred its loyalty to the new regime with ease and has continued with its typical foot-dragging mediocrity, but still relatively efficient performance. The 
TABLE 3.3

BRANCH STRUCTURE OF EARNINGS IN TWO HISTORICAL PERIODS

(per cent of the average)

\begin{tabular}{|c|c|c|c|c|c|c|}
\hline \multirow[t]{2}{*}{ Branch } & \multicolumn{2}{|c|}{ Czechoslovakia } & \multirow{2}{*}{$\begin{array}{l}\text { Change } \\
1948-53\end{array}$} & \multicolumn{2}{|c|}{ Czech Republic } & \multirow{2}{*}{$\begin{array}{l}\text { Change } \\
1989-97\end{array}$} \\
\hline & 1948 & 1953 & & 1989 & 1997 & \\
\hline Manufacturing & 92.6 & 107.9 & +15.3 & 104.4 & 100.3 & -4.1 \\
\hline Construction & 101.2 & 114.7 & +13.5 & 111.2 & 104.9 & -6.3 \\
\hline Agriculture & 80.2 & 72.1 & -8.1 & 108.2 & 79.5 & -28.7 \\
\hline Transport & 109.4 & 110.2 & +0.8 & 106.4 & 105.8 & -0.6 \\
\hline Trade & 102.6 & 90.0 & -12.6 & 83.8 & 98.3 & +14.5 \\
\hline Health and welfare & 120.9 & 92.1 & -28.8 & 90.1 & 90.0 & -0.1 \\
\hline Education & 124.8 & 90.0 & -34.8 & 89.8 & 88.1 & -1.7 \\
\hline Banking and insurance & 134.5 & 104.3 & -30.2 & 98.3 & 174.4 & +76.1 \\
\hline $\begin{array}{l}\text { Administration and } \\
\text { defense }\end{array}$ & - & - & - & 101.3 & 110.2 & +8.9 \\
\hline Average & 100.0 & 100.0 & 0.0 & 100.0 & 100.0 & 0.0 \\
\hline
\end{tabular}

Sources: Statistical Yearbooks.

maintenance of the state administration was considered to be one of the reasons for the smooth implementation of the Czech economic reform (Orenstein 1994). Against prevailing expectations, even after accomplishing the first steps of state withdrawal from the economy, the bureaucracy expanded both in the numbers and rewards: its number rose from 88,000 employees in 1989 to 172,000 employees in 1997 and the average salary improved its position in relation to the average wage from 102 in 1989 to 110 per cent in 1997.

The finance sector, including banking, insurance and all services offered to financial capital, has seen a spectacular rise since 1989. Once a part of the state administration under the communist regime, this category was transformed almost overnight into an elite group in terms of rewards and prestige. Its number rose from 25,000 employees in 1989 to 82,000 employees in 1997 and the average salary improved its position in relation to the average wage from 98 per cent in 1990 to 174 per cent in 1997 . No notable rise in productivity accompanied this growth as banking fully made use of both its sudden indispensability and monopoly position. Its inefficiency appeared manifestly and did not become an issue until 1997.

In contrast with finance, economy and law, public services lagged behind. This social category, represented among others by teachers, physicians and researchers, was not only excluded from the privatization process but was exposed to the expanding market with tight and often frozen budgets. Mainstream governmental politics was not favourably inclined towards these groups, despite the prominent position of 'human capital' in neoclassical economics (Becker 1975). The results of all their attempts to 
increase their salaries is - after some fluctuations - nothing. Despite a marked increase in the skill disparities of earnings, this process affects typical intellectuals to a lesser degree.

\subsection{Manual workers and farmers}

The transformation has destroyed all signs of the working class hegemony or any illusion of it. It is witnessed by changing branch composition, wage disparities and job securities. After a long period of stability under the command economy, the agriculture and manufacturing industries are rapidly diminishing in favour of tertiary branches. Despite the widespread hoarding of labour by privatized firms in the first years of transformation, manufacturing has finally reduced its personnel by one fifth, mostly in favour of trade and services. The privileged sections of the working class (mining, metallurgy, heavy machinery) have lost their position and their wage levels have sunk to near the average. Wage disparities widened to the disadvantage of manual workers, and unemployment started to affect workers with lower than secondary education (Table 3.4).

TABLE 3.4

ECONOMICALLY ACTIVE POPULATION AND EARNINGS ACCORDING TO EDUCATION (per cent)

\begin{tabular}{lrrrrrrrrr}
\hline Education & \multicolumn{3}{c}{ Total } & \multicolumn{3}{c}{ Men } & \multicolumn{3}{c}{ Women } \\
\cline { 2 - 10 } & \multicolumn{1}{c}{1988} & 1992 & 1996 & 1988 & 1992 & 1996 & 1988 & 1992 & 1996 \\
\hline Composition of the population: & & & & & & & \\
Elementary & 20.7 & 11.9 & 10.4 & 14.5 & 7.5 & 7.2 & 28.6 & 17.1 & 14.4 \\
Vocational & 41.6 & 46.5 & 47.1 & 48.8 & 53.8 & 55.2 & 32.4 & 38.0 & 37.3 \\
Secondary & 27.6 & 30.7 & 30.9 & 24.3 & 26.0 & 24.7 & 31.9 & 36.3 & 38.4 \\
Tertiary & 10.1 & 10.8 & 11.6 & 12.4 & 12.7 & 12.9 & 7.1 & 8.6 & 9.9 \\
Total & 100.0 & 100.0 & 100.0 & 100.0 & 100.0 & 100.0 & 100.0 & 100.0 & 100.0 \\
\hline Earnings: & & & & & & & & & \\
Elementary & 90.5 & 75.7 & 69.6 & 90.5 & 81.0 & 73.0 & 93.1 & 80.3 & 74.6 \\
Vocational & 95.4 & 92.9 & 87.6 & 95.4 & 90.3 & 85.9 & 93.9 & 85.2 & 81.8 \\
Secondary & 101.4 & 103.7 & 106.9 & 102.2 & 104.5 & 110.3 & 104.3 & 112.6 & 112.7 \\
Tertiary & 134.0 & 144.0 & 164.7 & 124.6 & 140.0 & 161.3 & 133.1 & 145.4 & 160.7 \\
Average & 100.0 & 100.0 & 100.0 & 100.0 & 100.0 & 100.0 & 100.0 & 100.0 & 100.0 \\
\hline
\end{tabular}

Sources: Microcensus 1988, 1992 and 1996.

Where state-socialist manufacturing saw considerable decline after 1989, cooperativesocialist agriculture experienced a true fall. Under the communist regime, collectivized agriculture was subsidized, while peasants could combine decent (and not taxed) earnings from cooperatives with income in kind from private plots. As privatization of cooperatives remained mostly in their hands, many peasants never got their property 
back. Also due to large openness to EU market, farming turned into an unprofitable activity. No surprise that farmers were much less supportive of reforms than other citizens. Despite of large differences in individual farmers' fates, agriculture usually does offer hardly more than simple surviving. This is witnessed by frequent mass actions of agricultural associations.

\subsection{The poor and socially deprived}

Liberalization of prices and the opening of the labour market has enlarged sections of the population exposed to poverty. Whereas under the communist regime, poverty was linked with the life cycle (the 'old' poverty), the new sources of inequality linked it to unemployment and low wages (the 'new' poverty). Although expectations of a widespread poverty are permanently high (Figure 3.1), the actual situation was not that gloomy, due to both low unemployment rate and quite generous social protection. However, we cannot talk here about poverty as such but about its concrete measurements:

FIGURE 3.1

POVERTY WILL BE ACUTE IN THE NEAR FUTURE (per cent)

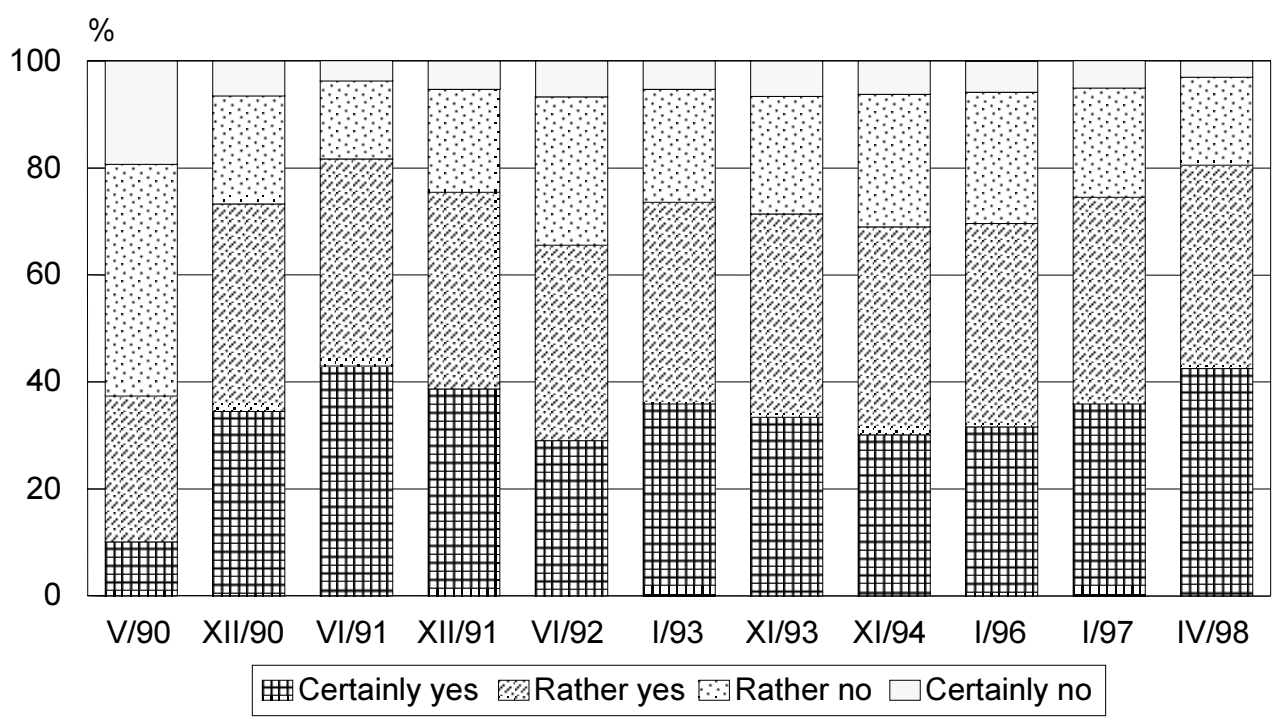

Source: EEA surveys.

Legal poverty. In 1991, the living minimum was established and is increased each time the rise in the living costs of households below the legal poverty line exceeds 10 per cent. The implicit equivalence scale of the calculation is very steep. ${ }^{20}$ According to the statistical income surveys, the percentage of households declaring incomes below the legal poverty line is falling (Table 3.5). The first decrease after 1988 was caused by the

20 Whereas household size elasticity is 0.8 in the Czech living minimum calculation, it is about 0.4 in Belgium, the Netherlands and Luxembourg and about 0.5 in France and Spain. 
fact that the new arrangement was stricter by definition but instead obligatory for the state. Another small decrease occurred due to the fact that in 1993, an amendment introduced stricter eligibility conditions, excluding people who are reluctant to work, change their job on insufficient grounds, or do not cooperate with the labour office.

TABLE 3.5

POOR HOUSEHOLDS AND PERSONS ACCORDING TO FAMILY STATUS

A. Percentage of poor in individual categories

\begin{tabular}{lrrrrrr}
\hline Family status & \multicolumn{3}{c}{ Legal poverty line } & \multicolumn{3}{c}{ EU poverty line } \\
\cline { 2 - 7 } & 1988 & 1992 & 1996 & 1988 & 1992 & 1996 \\
\hline Households: & & & & & & \\
Family with children & 1.1 & 3.2 & 2.7 & 0.7 & 2.0 & 6.3 \\
Single parent family & 8.1 & 10.2 & 8.3 & 5.0 & 7.5 & 16.4 \\
One person household & 13.5 & 1.4 & 1.0 & 19.9 & 2.6 & 3.9 \\
Other & 1.8 & 0.9 & 0.3 & 3.0 & 1.1 & 0.7 \\
Average & 4.5 & 2.7 & 2.1 & 6.1 & 2.3 & 5.0 \\
\hline Persons: & & & & & & \\
Family with children & 1.1 & 3.6 & 3.2 & 0.7 & 2.1 & 7.0 \\
Single parent family & 8.6 & 11.3 & 9.3 & 4.8 & 8.1 & 17.5 \\
One person household & 13.5 & 1.4 & 1.0 & 19.9 & 2.6 & 3.9 \\
Other & 1.6 & 0.9 & 0.3 & 2.6 & 1.1 & 0.7 \\
Average & 2.7 & 3.3 & 2.7 & 3.1 & 2.4 & 5.9 \\
\hline
\end{tabular}

B. Composition of poor according to family status

\begin{tabular}{lrrrrrr}
\hline Family status & \multicolumn{3}{c}{ Legal poverty line } & \multicolumn{3}{c}{ EU poverty line } \\
\cline { 2 - 7 } & 1988 & 1992 & 1996 & 1988 & 1992 & 1996 \\
\hline Households: & & & & & & \\
Family with children & 9.2 & 44.2 & 47.0 & 4.7 & 31.9 & 45.5 \\
Single parent family & 8.7 & 33.4 & 38.5 & 4.0 & 28.6 & 32.5 \\
One person household & 68.7 & 11.3 & 10.1 & 75.2 & 23.7 & 17.2 \\
Other & 13.5 & 11.2 & 4.3 & 16.1 & 15.8 & 4.8 \\
Total & 100.0 & 100.0 & 100.0 & 100.0 & 100.0 & 100.0 \\
\hline Persons: & & & & & & \\
Family with children & 24.1 & 59.3 & 61.7 & 13.6 & 49.3 & 63.0 \\
Single parent family & 15.8 & 29.0 & 32.3 & 7.6 & 28.7 & 28.2 \\
One person household & 43.0 & 3.5 & 2.9 & 55.0 & 8.7 & 5.4 \\
Other & 17.1 & 8.2 & 3.1 & 23.8 & 13.3 & 3.4 \\
Total & 100.0 & 100.0 & 100.0 & 100.0 & 100.0 & 100.0 \\
\hline
\end{tabular}

Sources: Microcensus 1989, 1992 and 1996.

EU poverty. The standardized relative definition considers as poor households whose income is below 50 per cent of the average (or median) income per equivalent adult, 
computed as 1.0 for the first adult, 0.7 for other adults and 0.5 for each child (O'Higgins and Jenkins 1990). In comparison with the legal poverty line, the weight of children is lower here, the weight of adults higher and the burden of common household costs also slightly higher. In the late $1980 \mathrm{~s}$, the percentage of poor was low in the former Czechoslovakia, affecting especially households of pensioners. After 1989, this proportion yet decreased, due to intervention policy affecting the bottom of the income distribution. But increasing income disparities in the mid-1990s brought about a higher proportion of poor households.

Feeling poor. Along the etatist and statistical definitions it is also useful to ask people themselves whether they feel poor. Perceived poverty is a relational feature dependent on the social environment and expectations. Low incomes could be purely transitional, without reflecting financial problems in the same way as actual poverty. Feeling poor seems to be rather more stable over time, amounting to about 8 per cent of households. The price liberalization in 1991 and the tax reform in 1993 caused a slight increase in the self-declaration of poverty. This indicator has risen again since 1997, reflecting the ongoing economic recession (Figure 3.2). Subjective poverty is especially striking in retirement age and unskilled people.

FIGURE 3.2

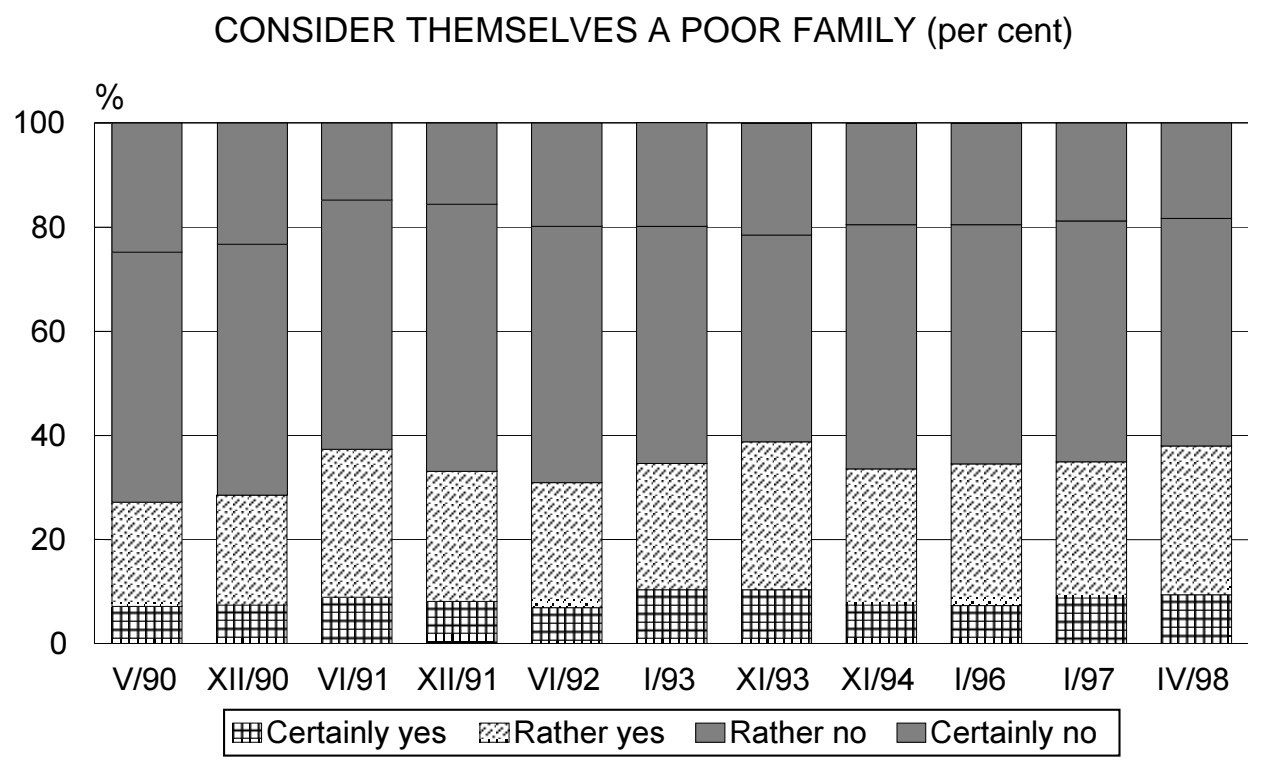

Source: EEA surveys.

The degree of social deprivation is generally low in the Czech Republic. This is caused by still quite low levels of income and wealth disparities, the good performance of the social system (and until 1997 also the economy), and the traditional democratic character of the society. There is also, however, the Roma ethnic which is minority extremely vulnerable to all the risks of the market economy, due to its very low skill level and weak labour commitment. Consequently, its unemployment rate nears to 30 per cent. On the other hand, this category of usually large families is substantially much attracted to and trapped by the steep benefits allocated according to living minimum. 


\section{SOCIAL RE-RANKING, STATUS INCONSISTENCY AND POLARIZATION}

The transformation has revealed social ranking instead of obscured picture of the former, apparently equalized but hidden unequal and polarized society (between 'the people' and the ruling class). Formerly hidden or officially non-existent disparities have become visible and the new inequalities partly strengthen and partly invert the old ones. Simultaneously, economic inequalities have ceased to be derived from political positions and have started to be produced by markets in a much higher degree. The first impetus was launched by privatization which lead the self-employed and entrepreneurs back onto the economic scene. But the most powerful factor is the labour market which produces large mobility. All of this, together with changes in income, has generated new patterns of social ranking.

Not only do people move within a given social space with settled dimensions but also this space is changing itself, and meanings of its various dimensions are changing too. Not only is individual mobility between stable social categories occurring but also a 'collective' mobility which changes the relations of the rewards and prestige of occupations. Moreover, the perception of these motions by people themselves may add yet something else, i.e. a comparison of 'objective' mobility (be it individual or collective) with 'subjective' evaluation (reflecting both the degree of satisfaction with the past and expectations towards the future). We also have to look behind usual socioeconomic categories and consider the degree of consistency between individual components of social standing.

\subsection{Objective mobility}

The best available dataset which is the survey Social Stratification in Eastern Europe after 1989 limits our comparative analysis of socio-economic composition and mobility of the population only up to $1993.21 \mathrm{We}$ can certainly assume that the main 'revolutionary' break occurred in the first years after 1989. However, changes have indeed continued even further in all possible directions: the rise of the category of selfemployed and entrepreneurs, together with expansion of white-collar workers, managerial and intellectual professions on the one hand, accompanied by a decrease in manual workers and farmers on the other hand.

In Table 4.1, we compare two periods of time (communist and post-communist) according to ten socio-economic categories in four CEE countries, using the EGP

21 In the analysis of the survey Social Stratification in Eastern Europe after 1989, we largely refer to interpretations and tables made by Petr Mateju (1999). 
classification. ${ }^{22}$ The result (summarized by index of dissimilarity) tells us that the change in socio-economic composition was much more intense after 1989 than before. In all countries the categories of manual workers and farmers decreased in favour of the self-employed and entrepreneurs, and also of lower professionals (mostly in the tertiary branches). Whereas categories of higher professionals have increased only a little (in the Czech Republic and Hungary) if at all (in Poland and Slovakia).

TABLE 4.1

CLASS STRUCTURE OF ECONOMICALLY ACTIVE POPULATION IN THE AGE GROUP 20-65 (per cent)

\begin{tabular}{lrrrrrr}
\hline \multicolumn{1}{c}{ Social class } & \multicolumn{3}{c}{ Czech Republic } & \multicolumn{3}{c}{ Hungary } \\
\cline { 2 - 7 } & 1983 & 1988 & 1993 & 1983 & 1988 & 1993 \\
\hline Higher professional & 8.5 & 9.4 & 9.1 & 7.6 & 8.4 & 8.6 \\
Lower professional & 14.0 & 15.5 & 16.8 & 11.9 & 12.7 & 15.2 \\
Routine non-manual & 14.2 & 14.0 & 14.1 & 11.9 & 12.7 & 14.1 \\
Self-employed w. empl. & 0.0 & 0.0 & 1.2 & 0.0 & 0.8 & 1.6 \\
Self-employed w/o empl. & 0.5 & 0.6 & 4.3 & 2.5 & 2.7 & 5.7 \\
Foreman, lower techn. & 4.7 & 5.0 & 3.9 & 4.4 & 4.1 & 3.3 \\
Skilled workers & 19.2 & 19.4 & 17.9 & 24.5 & 24.1 & 22.6 \\
Unskilled worker & 31.3 & 29.3 & 27.1 & 28.6 & 27.5 & 24.0 \\
Farm worker & 7.2 & 6.7 & 4.9 & 7.9 & 5.8 & 3.5 \\
Private farmer & 0.3 & 0.2 & 0.7 & 0.7 & 1.1 & 1.5 \\
Total & 100.0 & 100.0 & 100.0 & 100.0 & 100.0 & 100.0 \\
Index of change & $1983-88: 2.9$ & $1988-93: 6.9$ & $1983-88: 3.8$ & $1988-93: 8.2$ \\
\hline & \multicolumn{7}{c}{ Poland } & & Slovakia & \\
Higher professional & 10.3 & 10.2 & 9.2 & 10.3 & 11.0 & 10.1 \\
Lower professional & 12.3 & 12.2 & 13.1 & 14.1 & 14.9 & 17.5 \\
Routine non-manual & 15.5 & 16.1 & 16.3 & 14.3 & 14.6 & 14.3 \\
Self-employed w. empl. & 0.8 & 1.3 & 3.6 & 0.0 & 0.0 & 0.8 \\
Self-employed w/o empl. & 1.8 & 2.1 & 6.2 & 0.4 & 0.4 & 3.1 \\
Foreman, lower techn. & 4.0 & 3.4 & 2.8 & 4.9 & 4.9 & 4.6 \\
Skilled workers & 18.9 & 20.0 & 17.5 & 22.4 & 23.0 & 21.6 \\
Unskilled worker & 21.5 & 21.3 & 18.5 & 25.6 & 24.4 & 22.0 \\
Farm worker & 4.4 & 3.7 & 2.1 & 7.6 & 6.5 & 5.2 \\
Private farmer & 10.6 & 9.6 & 10.6 & 0.3 & 0.4 & 0.6 \\
Total & 100.0 & 100.0 & 100.0 & 100.0 & 100.0 & 100.0 \\
Index of change & $1983-88: 2.9$ & $1988-93: 8.5$ & $1983-88: 2.4$ & $1988-93: 6.3$ \\
\hline
\end{tabular}

Source: Social Stratification in Eastern Europe after 1989 (Mateju 1999).

Note: Index of change is in fact the dissimilarity index: $D=1 / 2 \sum\left|x_{i}-x_{j}\right|$, where $x_{i}$ and $x_{j}$ are the shares of corresponding classes in the economically active population.

22 Classification EGP is named after its authors (R. Erikson, J. H. Goldthorpe and Lucienne Portocarero) and based on Weberian class definition. The first criterion is economic status (entrepreneur, self-employed or employee), the second criterion is type of labour contract (degree of work autonomy and easiness to fire) and additional criteria are branch (for identifying farmers), position in hierarchy (higher and lower professionals) and skills (skilled and unskilled workers) (Erikson and Goldthorpe 1992). 
The picture of changes in socio-economic composition of the economically active population is certainly significant but far from impressive. The data witness that most changes evolved due to the markets and flows towards services but not by the modernization of the economy and society which should increase especially the share of professionals. Surprisingly, Hungary and Poland (where the category of self-employed existed even before 1989) scores higher in the change of population composition than the Czech Republic and Slovakia in which the self-employed represented a negligible category and occupational mobility was also very weak.

Social mobility is, however, not limited by a given structure but includes also 'circulation' between individual categories. In Table 4.2, we distinguish strong upwards or downwards mobility (by two and more classes), simple mobility (by one category) and stability, while leaving apart movements to the self-employed, unemployment and early retirement. Again, we find the greatest stability but also the smallest downward mobility and greatest inflow to self-employed in both countries of former Czechoslovakia. In contrast, Hungary and Poland show extensive inflows into unemployment and also early retirement (pushed by the labour market and pulled by legislation).

TABLE 4.2

INTRAGENERATIONAL CLASS MOBILITY OF PERSONS IN WORKING AGE (per cent)

\begin{tabular}{lrrrrrrrrr}
\hline \multirow{2}{*}{ Type of mobility } & \multicolumn{3}{c}{$\begin{array}{c}\text { Czech } \\
\text { Republic }\end{array}$} & \multicolumn{2}{c}{ Hungary } & \multicolumn{2}{c}{ Poland } & \multicolumn{2}{c}{ Slovakia } \\
\cline { 2 - 9 } & $83-88$ & $88-93$ & $83-88$ & $88-93$ & $83-88$ & $88-93$ & $83-88$ & $88-93$ \\
\hline Significantly decreased & 1.9 & 3.2 & 2.3 & 2.7 & 2.3 & 2.2 & 2.0 & 2.2 \\
Decreased & 2.4 & 3.8 & 3.5 & 3.4 & 3.0 & 4.2 & 2.3 & 3.8 \\
No change & 86.7 & 70.0 & 81.1 & 57.7 & 80.8 & 60.0 & 88.0 & 68.8 \\
Increased & 3.6 & 3.4 & 3.7 & 3.5 & 4.0 & 3.9 & 2.9 & 3.0 \\
Signicantly increased & 3.3 & 3.5 & 3.6 & 3.3 & 3.9 & 3.4 & 2.7 & 3.2 \\
To self-employed & 0.2 & 8.9 & 2.2 & 5.6 & 2.7 & 7.7 & 0.2 & 6.1 \\
To unemployed & 0.0 & 1.9 & 0.3 & 14.2 & 0.4 & 10.2 & 0.0 & 7.6 \\
Early retirement & 1.8 & 5.1 & 3.3 & 9.6 & 2.7 & 8.4 & 1.8 & 5.3 \\
Total & 100.0 & 100.0 & 100.0 & 100.0 & 100.0 & 100.0 & 100.0 & 100.0 \\
\hline
\end{tabular}

Source: Social Stratification in Eastern Europe after 1989 (Mateju 1999).

\subsection{Subjective mobility}

In the measurement of objective mobility, we are always limited by indicators which can hardly cover all the possible movements of people having some effect on their position (increase or decrease in rewards, prestige, working conditions or job satisfaction). Along with vertical movements, important horizontal movements also occur (change in position within a firm or change of employer) which might lead to an improvement or 
worsening in rewards, work conditions and satisfaction. In addition, and especially in periods of regime change, the position of social classes and categories may change in ways that even a worker who stays in the same job, doing the same work might perceive a shift in its individual position.

For all that, it is useful to ask not only about changes in occupation and firm, but also about change in position, as it is perceived by people themselves. When we did this we found that the percentage of subjectively stable people was much lower than the percentage of objectively stable. In Table 4.3, there is a distinction between strong upwards and downwards movements (three or more points on a 10-category scale of social position), simple mobility (by one or two points) and stability (no change). In comparison, the Czech population demonstrated the greatest stability and upwards mobility, contrasting with the three other transition countries where the perception of social deprivation was higher (about 15 per cent).

TABLE 4.3

SUBJECTIVE MOBILITY OF ECONOMICALLY ACTIVE PERSONS (per cent)

\begin{tabular}{lcccrr}
\hline \multicolumn{1}{c}{ Type of mobility } & Czech Republic & Hungary & Poland & Slovakia & Total \\
\hline Significantly decreased & 10.5 & 13.1 & 15.4 & 15.1 & 13.3 \\
Decreased & 23.5 & 43.6 & 29.0 & 31.0 & 30.8 \\
No change & 46.3 & 32.2 & 36.7 & 39.8 & 39.7 \\
Increased & 16.6 & 9.6 & 14.7 & 11.9 & 13.5 \\
Significantly increased & 3.1 & 1.5 & 4.2 & 2.1 & 2.7 \\
Total & 100.0 & 100.0 & 100.0 & 100.0 & 100.0 \\
\hline
\end{tabular}

Source: Social Stratification in Eastern Europe after 1989 (Mateju 1999).

Only about a half of objectively stable respondents in the Czech Republic, and even fewer in the other countries declared stability in subjective terms (Table 4.4). But it was also possible for people declaring objective upwards mobility could declare a downwards subjective mobility. Results generally witness a vast independence between the two types of mobility and refer to the extensive collective mobility of nominally similar categories. The advancing social groups were especially professionals (the higher more than lower), self-employed (entrepreneurs and freelance more than simple independent workers) and, consequently, people with higher education. An interesting point is the effect of political background: while simple membership in the Communist Party appeared to have no effect on subjective mobility, membership to party cadres has a positive effect, mostly due to providing the 'social capital' that helps when starting a business. 
TABLE 4.4

SUBJECTIVE MOBILITY OF ECONOMICALLY ACTIVE PERSONS WHO HAVE NOT CHANGED THEIR SOCIAL CLASS BETWEEN 1988-93 (PER CENT)

\begin{tabular}{lcccrr}
\hline Type of mobility & Czech Republic & Hungary & Poland & Slovakia & Total \\
\hline Significantly decreased & 9.4 & 13.0 & 16.1 & 15.7 & 13.2 \\
Decreased & 25.1 & 43.5 & 29.2 & 33.4 & 32.0 \\
No change & 48.9 & 33.6 & 38.1 & 39.9 & 41.2 \\
Increased & 14.3 & 8.5 & 13.0 & 9.6 & 11.5 \\
Significantly increased & 2.3 & 1.3 & 3.7 & 1.5 & 2.1 \\
Total & 100.0 & 100.0 & 100.0 & 100.0 & 100.0 \\
\hline
\end{tabular}

Source: Social Stratification in Eastern Europe after 1989 (Mateju 1999).

Note: $\quad$ Only persons who appear in Table 4.2 belong to category 'stability'.

\subsection{Status inconsistency}

The relationship between objective and subjective mobility refers to status consistency/inconsistency. In theoretical and normative terms, the ideal model of social stratification in market economy is expressed by the 'meritocratic triad' of education, occupation and income. An individual's qualifications should be convertible into an appropriate occupational position and this position should again be provided with corresponding earnings (Kreckel 1992: 97). Achievement ideology legitimates the income inequality which is supportive of economic efficiency and growth. It creates a vertical stratification whereby people are distinguished by their human capital, occupational prestige and income rewards. ${ }^{23}$

Since the harmony of education, occupation and income can never be reached, we can only measure how the system is gradually adjusting to this standard. If the market mechanism replaces the centralized bureaucratic allocation of jobs and administration of wages, we can expect that all three dimensions of social status will stream towards more consistency. The market process concerns especially the distribution of earnings which was the main source of inconsistency under the communist regime (Machonin et al. 1969). As the inequality in rewards increases and correlation between earnings and education rises, the whole cluster of market characteristics of individuals becomes more bound.

Indeed, survey data over time (not only retrospective) also witness growing consistency of education, job and income. In Table 4.5, we reproduce analysis done by Petr Mateju

23 In this approach, the theory of human capital (Mincer 1974) is closely interconnected with the 'status attainment' perspective (Sewell and Hauser 1975; Featherman and Hauser 1984), according to which the supply side of the labour market is complemented by social background and the measurement of occupational status is refined. 
TABLE 4.5

OBJECTIVE STATUS CONSISTENCY: THE RESULTS OF EXPLORATORY FACTOR

ANALYSIS METHOD: PRINCIPAL COMPONENTS ANALYSIS, OBLIMIN ROTATION, PATTERN MATRICES

\begin{tabular}{|c|c|c|c|c|c|c|}
\hline & \multicolumn{2}{|c|}{1991} & \multicolumn{2}{|c|}{1995} & \multicolumn{2}{|c|}{1997} \\
\hline & SES-CON & SES-INC & SES-CON & SES-INC & SES-CON & SES-INC \\
\hline $\begin{array}{l}\text { Explained variance (in } \\
\text { per cent) }\end{array}$ & 57.2 & 31.7 & 63.0 & 27.8 & 65.1 & 26.1 \\
\hline \multicolumn{7}{|l|}{$\begin{array}{l}\text { Factor loadings before } \\
\text { rotation }\end{array}$} \\
\hline Education & 0.901 & -0.136 & 0.899 & -0.223 & 0.896 & -0.249 \\
\hline $\begin{array}{l}\text { Index of socio-economic } \\
\text { status }\end{array}$ & 0.878 & -0.262 & 0.884 & -0.289 & 0.887 & -0.289 \\
\hline Income & 0.383 & 0.922 & 0.545 & 0.837 & 0.602 & 0.798 \\
\hline \multicolumn{7}{|l|}{$\begin{array}{l}\text { Factor loadings after } \\
\text { oblique rotation }\end{array}$} \\
\hline Education & 0.897 & 0.067 & 0.915 & 0.037 & 0.923 & 0.023 \\
\hline $\begin{array}{l}\text { Index of socio-economic } \\
\text { status }\end{array}$ & 0.925 & -0.061 & 0.940 & -0.034 & 0.941 & -0.021 \\
\hline Income & 0.001 & 0.998 & 0.008 & 0.999 & 0.000 & 0.999 \\
\hline $\begin{array}{l}\text { Factor correlations (after } \\
\text { rotation) }\end{array}$ & \multicolumn{2}{|c|}{0.153} & \multicolumn{2}{|c|}{0.291} & \multicolumn{2}{|c|}{0.345} \\
\hline
\end{tabular}

Source: Social Justice 1991 and 1995, ISSP 1997 (Mateju and Kreidl 1998).

Notes: Variables:

Education: The highest achieved education (8 categories) Index of socioeconomic status: International Index of Socioeconomic Status (ISEI) Income: Net personal income from all economic activities.

which shows inter-relations between job position measured on the ISEI scale, 24 education and income of economically active respondents in three surveys (Mateju and Kreidl 1998). As the explained variance in the top part of the table shows, the percentage of consistent component of socio-economic status had increased and the percentage of the inconsistent component had decreased. Simultaneously, income joined the consistent part in an increasing degree. In the bottom part of the table, the most relevant information is the correlation between both axes of socio-economic status which strengthened from 0.15 in 1991 to 0.34 in 1997.

24 International Socio-Economic Index of Occupations, based on 31 surveys in 16 countries, ranges between 0 and 96 and according to its authors (Ganzeboom, De Graaf and Treiman 1992) is not a prestige scale but indicates how much human capital converts into income. 


\subsection{Social re-ranking in 1989-99}

The surveys tell us not only about an increasing consistency between job position, education and income, but also about growing links between the objective situation and subjective location in the social hierarchy. In early 1999, we asked people to locate themselves on ladders representing social position, income and standard of living, both now and as they were ten years ago. When using such a long retrospective horizon, it is necessary to be very cautious. Usually, people are much more critical towards the present than towards the past: as the communist regime moves further back into history, people remember rather its positive features such as social guarantees and tend to forget its drawbacks such as the modest supply of goods and services (not to mention about political freedoms). Similarly, the reference levels change too: what might be taken as a decent standard under communism, is considered as a near poverty situation today.

Table 4.6 ( $a$ and b) summarizes self-ranking on social and income ladders in 1989 and 1999, and the corresponding change over time. We may conclude the following: (1) A decrease occurred in all three types of ranking but not by more than one point on the 10item scale on average; (2) In 1999, the population is generally more dispersed on all three scales, especially lower on the scale; (3) The overwhelming trend is rather an exchange of position and not polarization - correlation coefficients between positions in 1989 and 1999 are very weak ( 0.24 for social position, 0.15 for income and 0.08 for the standard of living); while from the perspective of 1989, the lower positions increase and the higher ones decrease, from the perspective of 1999, the opposite is true; (4) There is more consistency between the three types of positions in 1999 than in 1989 (as the comparison of correlation coefficients in both years witness).

What are the factors of both the position in 1999 and its change since 1989? Who are the 'winners' and 'losers' of transformation, according to people themselves? This is approximated by correlation coefficients of social positions and mobility with various characteristics of people (Table 4.7). Regarding the static position in 1999, the most important factors of perceived deprivation are retirement, unemployment and low education level. By contrast, those people who feel significantly better-off tend to be the self-employed or entrepreneurs, and people with higher education. Within the labour force, age, the size of locality and the number of children seem to have no effect. Regarding the change of position in 1989-99, labour force participation, selfemployment and education all appear important in various degrees. In addition, younger people declare more intensive advancement on the social and income hierarchy than older ones.

\subsection{The social costs of transformation}

When surveying all the various changes in job, education and income inequalities and detecting their inter-relationships, it is difficult to precisely distinguish between the 'market conform' functional inequalities replacing former equalization and the need to ensure work performance and consequently also economic efficiency on the one hand, and the painful 'social costs' of the economic transformation involving futile impoverishment of the population and thus distortion of social integration on the other. 
TABLE 4.6a

SELF-RANKING ACCORDING TO SOCIAL POSITION, INCOME AND STANDARD OF LIVING (per cent)

\begin{tabular}{lrrrrrr}
\hline \multirow{2}{*}{ Decile scale } & \multicolumn{2}{c}{ Social position } & \multicolumn{2}{c}{ Income } & \multicolumn{2}{c}{ Standard of living } \\
\cline { 2 - 7 } & 1989 & 1999 & 1989 & 1999 & 1989 & 1999 \\
\hline 1 lowest & 2.0 & 4.2 & 4.6 & 5.7 & 1.6 & 4.0 \\
2 & 3.4 & 7.9 & 6.3 & 11.9 & 3.8 & 11.7 \\
3 & 8.5 & 15.5 & 15.2 & 17.4 & 12.0 & 15.9 \\
4 & 13.4 & 17.7 & 18.3 & 18.5 & 18.6 & 19.2 \\
5 & 17.5 & 17.4 & 26.1 & 20.8 & 30.3 & 21.9 \\
6 & 30.2 & 26.0 & 12.2 & 12.9 & 15.2 & 14.2 \\
7 & 13.6 & 7.6 & 10.2 & 7.6 & 10.2 & 8.2 \\
8 & 7.8 & 3.2 & 5.3 & 3.8 & 6.4 & 3.9 \\
9 & 2.9 & 0.3 & 1.4 & 1.0 & 1.3 & 0.7 \\
10 highest & 0.8 & 0.1 & 0.5 & 0.3 & 0.5 & 0.3 \\
Total & 100.0 & 100.0 & 100.0 & 100.0 & 100.0 & 100.0 \\
\hline
\end{tabular}

Source: ISSP-1999.

TABLE 4.6b

CHANGE IN SELF-RANKING ACCORDING TO SOCIAL POSITION, INCOME AND STANDARD OF LIVING (MEAN CHANGE IN POINTS OF THE DECILE SCALE)

\begin{tabular}{lcccccc}
\hline \multirow{2}{*}{ Decile scale } & \multicolumn{2}{c}{ Social position } & \multicolumn{2}{c}{ Income } & \multicolumn{2}{c}{ Standard of living } \\
\cline { 2 - 7 } & 1989 & 1999 & 1989 & 1999 & 1989 & 1999 \\
\hline 1 lowest & 2.0 & -3.3 & 2.3 & -2.7 & 2.6 & -3.6 \\
2 & 1.5 & -2.8 & 1.9 & -2.4 & 1.8 & -2.7 \\
3 & 1.1 & -2.1 & 1.0 & -1.8 & 1.2 & -2.1 \\
4 & 0.3 & -1.4 & 0.3 & -0.7 & 0.4 & -1.1 \\
5 & -0.4 & -0.5 & -0.5 & 0.2 & -0.4 & 0.0 \\
6 & -1.1 & 0.1 & -1.3 & 1.4 & -1.3 & 1.0 \\
7 & -2.2 & 1.2 & -2.2 & 1.9 & -2.5 & 1.8 \\
8 & -2.7 & 2.0 & -3.7 & 2.7 & -3.8 & 2.8 \\
9 & -3.7 & 2.2 & -4.4 & 2.9 & -4.8 & 3.1 \\
10 highest & -5.8 & 1.0 & -5.6 & 2.8 & -4.8 & 2.4 \\
Total & -0.8 & -0.8 & -0.4 & -0.4 & -0.6 & -0.6 \\
\hline
\end{tabular}

Source: ISSP-1999. 
TABLE 4.7

CORRELATION OF SELF-RANKING ACCORDING TO SOCIAL POSITION, INCOME AND STANDARD OF LIVING IN 1999 AND THEIR CHANGE IN 1989-99 WITH CHARACTERISTICS

OF RESPONDENTS (SPEARMAN COEFFICIENTS)

\begin{tabular}{lcccccc}
\hline Characteristic & $\begin{array}{c}\text { Social } \\
\text { position }\end{array}$ & Income & $\begin{array}{c}\text { Standard } \\
\text { of } \\
\text { living }\end{array}$ & $\begin{array}{c}\text { Change in 1989-99 } \\
\text { Social } \\
\text { position }\end{array}$ & Income & $\begin{array}{c}\text { Standard of } \\
\text { living }\end{array}$ \\
\hline Sex & -0.10 & -0.07 & -0.04 & -0.04 & -0.02 & -0.00 \\
Age & -0.06 & -0.02 & -0.04 & $-0.13^{*}$ & $-0.17^{*}$ & -0.07 \\
Education & $0.34^{*}$ & $0.24^{*}$ & $0.29^{*}$ & $0.17^{*}$ & $0.16^{*}$ & $0.23^{*}$ \\
Size locality & 0.02 & 0.08 & 0.09 & -0.01 & 0.06 & 0.08 \\
Self-employed & $0.20^{*}$ & $0.13^{*}$ & $0.16^{*}$ & $0.23^{*}$ & $0.12^{*}$ & $0.15^{*}$ \\
No. of children & -0.02 & -0.04 & -0.03 & 0.02 & 0.01 & 0.04 \\
Unemployment & $-0.23^{*}$ & $-0.27^{*}$ & $-0.26^{*}$ & $-0.24^{*}$ & $-0.18^{*}$ & $-0.23^{*}$ \\
Retirement & $-0.25^{*}$ & $-0.20^{*}$ & $-0.22^{*}$ & $-0.20^{*}$ & $-0.18^{*}$ & $-0.18^{*}$ \\
\hline
\end{tabular}

Source: ISSP-1999.

Notes: All indicators only for respondents in the labour force, except variable 'retirement' which is valid for the all population.

All coefficients marked * are significant at the level $<0.001$.

Indeed, market adjustment requires getting rid of excessive or unproductive labour for social (but under the communist regime also for political) reasons. Hence, it is necessary to dismantle the old system of social guarantees based on compulsory work. Earnings disparities, instead of reflecting the costs of reproduction of the labour force, primarily the need to serve as incentives for using and developing human capital, for good quality work. Economically functional inequality is more likely to be accepted as socially legitimate by the population.

However, if inequalities become extreme and especially when they are produced by illegitimate means (based on rent-seeking), the web of societal integration is faced with collapse. This might have serious adverse consequences in the economic, social and political spheres. Economically, demotivation outweighs commitments to work in the majority of the population and overall productivity of labour therefore falls. Socially, relative poverty (if not starvation) expands and produces large dissatisfaction amongst families. And politically, unsatisfied people blame the regime, finally giving up on democratic procedures and turning to extremist parties (Večerník 1996, chapter 11).

Regarding poverty, its indicators are not that bad in the Czech Republic, due to the relatively good performance of the economy and efficient social protection. The other question is, however, the near future. The economy is in recession, the rate of 
unemployment is rising fast and wages were stagnating between 1996 and 1998.25 So far, dissatisfaction with the financial situation is increasing in a slow but steady fashion (Figure 4.1). It is highly probable that the indicators of standard of living and corresponding satisfaction will worsen in response to the deterioration of the economic situation and absence of strategies to turn it round.

FIGURE 4.1

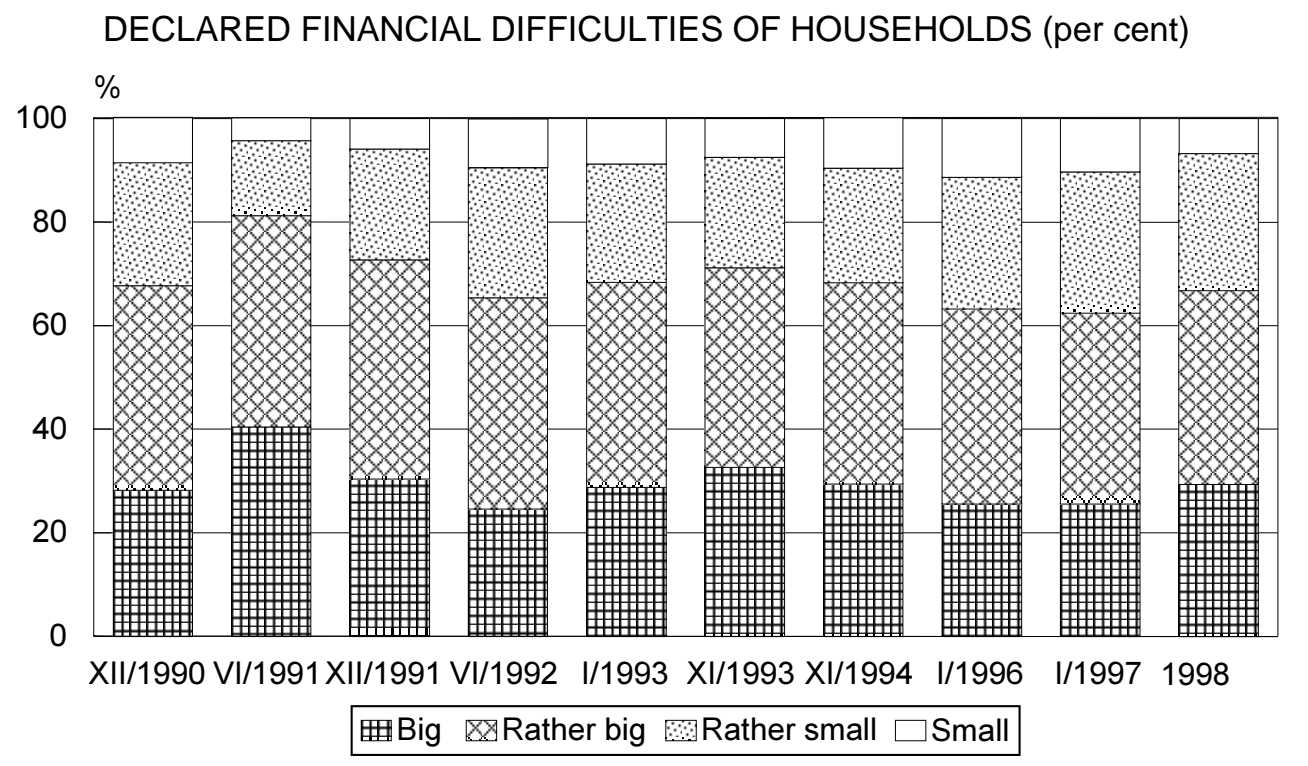

Source: EEA surveys.

It is not easy to measure social cohesion. One available indicator is the perception of conflicts between various categories of population. In Figure 4.2, we compare people's opinions on how sharp in their minds conflicts were in late 1992 and early 1999. There was an increase of perceived conflicts between the rich and poor and between young and old. Generally, the most important change is that the percentage of people answering that they 'cannot decide' decreased in all questions (again especially regarding conflict between the rich and the poor). But those people opted for the mild variants rather than the sharp ones.

The other results are as follows: (1) Generally, people do not perceive conflict as having sharpened over time. If we count views on all conflicts together, only in both years about 18 per cent of respondents saw a very sharp conflict in at least one area; (2) Cumulation of various perceived conflicts has not increased either because in both years only about 5 per cent of respondents saw a very sharp conflict and about 35 per cent saw some very sharp or sharp conflicts in more than one area; (3) Whereas in 1992, no

25 By 1999, tariff wages in the public sector were increased by 17 per cent due to their real decrease over recent years. In the expectation of 'standard' (about 10 per cent) inflation, numerous collective agreements were concluded for 1999 which oblige employers to ensure a rise in wages. In fact, inflation is very low due to restrictive monetary policy. Wage increase is higher in firms with remaining state ownership than in purely private firms. 
FIGURE 4.2

PERCEPTION OF CONFLICTS BETWEEN VARIOUS CATEGORIES (per cent)

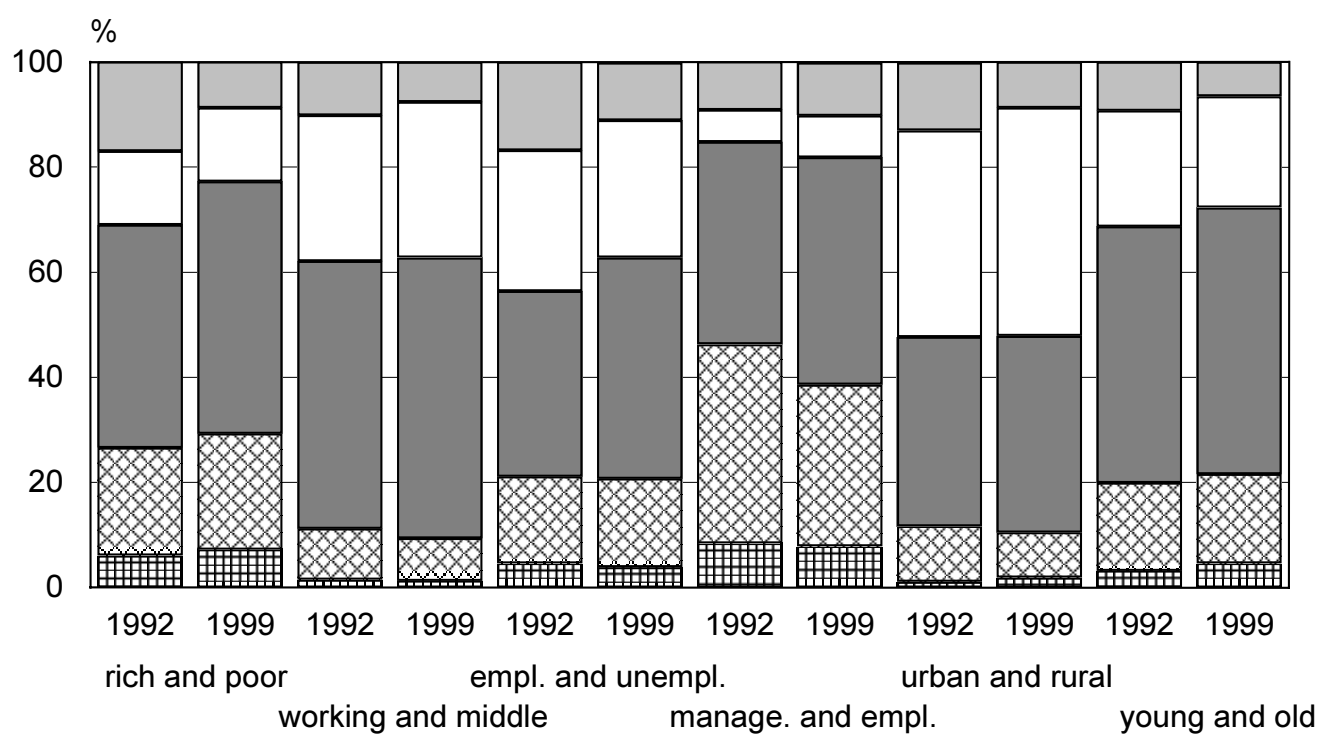

Very sharp $\otimes$ Sharp $\square$ Not very sharp $\square$ No $\square$ Cannot decide

Source: ISSP surveys.

correlation occurred between perception of conflict and subjective position in social hierarchy, there is a significant correlation in 1996 with both the perceived status and its change in 1989-99 (about 0.10); (4) There is no other social pattern of perception of conflicts except a stronger sensitiveness of women in the labour force to relationships between employers and employees.

Observed levels of conflicts are certainly not negligible. Moreover, we have to take into consideration that the most marginalized population usually escapes such type of survey. But the fact that there has not been significant increase over time witnesses that the Czech society is not endangered by social polarization, at least for the time being. In 1992, the Czech Republic belonged among countries with the lowest levels of perceived conflicts, along with Austria and Scandinavian countries, and in contrast to the other transition countries but also to liberal countries like United Kingdom or USA. We can only hope that the coming economic difficulties will not change this feature. 
The implosion of the communist regime in 1989 engendered substantial changes in all dimensions and areas of socio-economic inequality. Not only was the falseness of the ideological facade of large 'brotherhood classes' and homogeneous society unveiled, but also actual social stratification, combining equalized conditions for the great majority of people with privileges for the ruling class, was set in radical motion. Many former inequalities have become more apparent and, simultaneously, new disparities have been caused by market forces in the informal economy. Inequalities have started to widen and cumulate. Due to their more manifest character, it has become easier to observe them, but unfortunately still not easy enough to be able to provide an exhaustive picture.

When surveying all the various changes in economic inequalities, it is difficult to accurately distinguish between the 'market conform' functional inequalities replacing the former equalization and the need to ensure economic efficiency on the one hand, and the excessive 'social costs' of the economic transformation involving the futile impoverishment of the population and thus distortion of social integration on the other. Indeed, market adjustment requires getting rid of excessive or unproductive labour for social or - even - political reasons. Hence, it is necessary to dismantle the old system of social guarantees based on compulsory work and replace it with a new system, based on social insurance for all citizens and state assistance for the poor.

Privatization and liberalization of the economy created a huge concentration of income and wealth, largely hidden from public view. If inequalities become extreme, especially if produced by illegitimate means (based on rent-seeking), the web of societal integration will be faced with collapse. This might have serious adverse consequences in the economic, social and political spheres. Economically, disincentives could start to outweigh commitments to work in the majority of the population and in such case overall productivity of labour therefore would fall. Socially, relative poverty (if not starvation) would become more widespread and produce considerable dissatisfaction amongst families. And politically, dissatisfied people tend to blame the regime, eventually giving up on democratic procedures and turning to extremist parties.

In the Czech Republic, the data indicate an extensive adaptation of the economic system to a standard market economy. While the income distribution range is widening, demographic factors (as an expression of the 'need principle' and state control over the reproduction of the workforce) are gradually being replaced by economic factors in the determination of income (which indicate the growing strength of market forces). New social groups have emerged, such as the self-employed and entrepreneurs, and an important shift towards the tertiary sector in branch structure of the labour force has occurred. Simultaneously, powerful forces of the past supported a great deal of continuity in management and the bureaucracy, and this has been paralleled by weak restructuring of the economy and a slow adaptation of state institutions to serve the democratic society. 
In fact, few social categories fit a simplistic picture of 'winners' and 'losers' of transformation: those who are clearly winning are entrepreneurs and the self-employed (despite the sometimes illegal ways of attaining their success), and those who are clearly losing are formerly privileged sections of the working class and cooperative farmers (despite the welcomed restitutions of agricultural property). However, the overwhelming majority of the population need to be described using more subtle measurements, due to complexity of transition which involves many discrepancies and compensations. A discrepancy can be observed between objective mobility and its subjective reflection which includes all possible 'horizontal' motions, 'collective' mobility and other personal gains and losses not accessible by statistical tools. A compensation can be seen between the difficult starting conditions and the attractive perspectives for educated people.

Although income inequality has grown, the degree of poverty was kept rather low, due to the still good performance of the economy (up until 1997) and efficient social protection, transformed on the principle of targeting. However, as radical changes in the economy and institutions were postponed, the Czech Republic of the late 1990s is faced with a rather gloomy perspective, indicated by falling GDP, rising unemployment and growing discontent among the population. Increasing inequalities in income and wealth, perceived mostly as illegitimate, feed nostalgia for the past and undermine political support for the successful completion of the economic and societal transformation. Despite a strengthening of redistribution through taxes and subsidies, social and regional disparities have tended to deepening, fuelling support for the communists and their radical solutions to bring the state back into the economic process and restore equality.

In view of this, the main failure of the development after 1989 appears: limited expansion of the middle class. It is contended here that the middle class is not only the result but the foremost important condition of a successful transformation and the guarantee of its durability, because is has a fundamental and integrative role in the key areas of social and economic life. Its value system fully corresponds to an open democratic society and its central location between capital and labour ensures the integration of the society. The economic activities of its various sections supports the main structures of an efficient economy: dynamic markets, rich information flows and functioning institutions. In the political life, it avoids extremes and it displays enough patience not to outrun the slow pace of elections.

It can be seen that the Czech economic reforms have not been as beneficial to the emergent middle class as expected. The government was much more interested in the transformation of existing enterprises than in the creation of favourable conditions for the new entrepreneurs. It allowed the expansion of the financial and administrative sectors but it neglected the public services of health, education and research. The core middle-class groups - such as teachers, doctors and researchers - have been frustrated by their inferior status, a situation many qualified people have solved by downgrading their skills and moving to private firms. The quality of public services has been deteriorating, thus endangering the development of human capital. 
Despite all the recent gains in entrepreneurial freedom, in the use and development of skills, and in economic rewards and prestige, the middle class has been rather constrained in its expansion. This may have important consequences for future social stratification: whereas the upper classes will advance without limits, the poor will remain always well protected at the subsistence level and the middle strata can expand unevenly and with difficulties. It means that this could result in a social polarization even if the lowest income category remains small even though some sections of middle class will move closer to it.

To sum up, it appears the changes in social hegemonies has been less extensive than expected. The same findings can also be confirmed by the use of the concept of a hidden 'social contract' between the regime and the population. The contract asserted by the communist regime was concluded with the lower strata and its secured basic work and income for them and income equalization of the rest for the population. Because this contract was not accepted by a typical middle-class society, like the pre-communist Czech lands, it had to be supplemented by totalitarian rule. However, in a democratic system such a contract represents the sole base of social integration. The expectation here was that the new partner for the post-1989 regime will be above all the middle class and that the contract will, above all, guarantee to it equal opportunities in exchange for its support for full economic liberalization.

However, it seems that the government favoured much more the higher rather than the middle class, through the preferential treatment of the managers of former large stateowned companies, the permissive attitude toward the abuse of the system by the former nomenclatura members and huge redistributional flows from the middle income categories to the top, through the toleration of fraud by small consumers, people with savings, and small shareholders. The slow transformation of institutions and their weak performance has obviously damaged much more the ordinary people than the upper few, a 'more equal chance' was given to the banking sector, top state administration and large companies than to education, health services and new entrepreneurs - a policy which cherished and the latter felt squeezed by it.

It turned out that in fact, the new political elite concluded the imaginary contract with the upper strata - financial capital, top management and bureaucracy, many of whose members belonged to the former nomenclatura - rather than to the middle class. The widespread continuity of positions at the top was paralleled by maintaining the attitudes of the majority of the population. This was manifested by a shifting of opinions to the left and by increasing expectations of state protection. It resulted in a growing discontent with the 'liberal' (but in fact near to anarcho-liberal) tax and business policy and in a lower support for the 'residual' social policy. This could undermine the legitimacy of the existing redistributive system as a whole. 


\section{DATA SOURCES}

\section{Statistical surveys:}

Microcensus surveys started in 1958 as income surveys based on 1-2 per cent sample of households with wages confirmed by employers and pension benefits confirmed by post offices. They were regularly repeated every 3-5 years. Here, we use especially three last surveys:

Microcensus 1988 was conducted by the Federal Statistical Office on a 2 per cent random sample $(\mathrm{N}=69912)$ in March 1989 including yearly incomes in 1988.

Microcensus 1992 was conducted by the Czech Statistical Office on a 0.5 per cent random sample (N=16234) in March 1993 including yearly incomes in 1992.

Microcensus 1996 was conducted by the Czech Statistical Office on a 1 per cent random sample (N=28148) in March 1997 including yearly incomes in 1996.

\section{National sociological surveys:}

Economic Expectations and Attitudes (EEA) is a semi-annual (1990-92) or annual (1993 onwards) survey organized by the socio-economic team of the Institute of Sociology of the Academy of Sciences headed by Jiří Večerník. The samples involve between 1000 and 1500 adults selected by a two-step quota sampling procedure, whereby the region and size of the locality were defined in the first step and gender, age and education in the second. Collected by the Centre for Empirical Surveys STEM.

\section{Comparative sociological surveys:}

Social Stratification in Eastern Europe after 1989. International comparative research project conducted in 1993 under heading of Donald J. Treiman and Ivan Szelenyi, University of California in Los Angeles. National samples of the Czech Republic, Slovakia, Hungary, Poland, Russia and Bulgaria involve about 5000 adult respondents from each country. Czech data collected by the Czech Statistical Office. In order to produce household-specific characteristics, the person-level data were reweighted using the variable of the size of households. Income indicators refer to 1992.

ISSP (International Social Science Programme). Here we use especially the following modules: Social Inequality (1992), Work Orientations (1997) and Social Inequality (1999). Czech data collected by the Centre for Empirical Surveys STEM.

Perception of Social Justice. Survey conducted in 1991 by the International Social Justice Project, the survey includes 13 countries, among them Czechoslovakia, East Germany, Poland, Hungary, Russia and Slovenia. Repeated in the Czech Republic in 1995 and in 1999 (together with ISSP module Social Inequality). 


\section{APPENDIX TABLES AND FIGURES}

TABLE A1

EMPLOYED PERSONS ACCORDING TO THE BRANCH OF EMPLOYMENT (per cent)

\begin{tabular}{lrrrrrrrr}
\hline Branch & 1970 & 1980 & 1990 & 1991 & 1992 & 1993 & 1995 & 1997 \\
\hline Manufacturing industry & 41.1 & 40.1 & 38.1 & 37.4 & 36.2 & 34.9 & 32.7 & 32.5 \\
Construction & 7.4 & 7.9 & 7.8 & 8.0 & 8.3 & 9.4 & 8.8 & 8.9 \\
Agriculture & 15.8 & 12.3 & 11.4 & 9.8 & 7.8 & 6.8 & 6.0 & 6.2 \\
Transport and & 6.7 & 6.6 & 7.1 & 7.5 & 7.5 & 7.5 & 7.2 & 7.1 \\
$\quad$ communications & & & & & & & & \\
Trade and catering & 7.9 & 9.2 & 9.2 & 9.9 & 11.3 & 12.8 & 14.6 & 17.8 \\
Health and welfare & 3.7 & 4.6 & 5.2 & 5.4 & 5.6 & 5.5 & 5.3 & 5.2 \\
Education & 4.4 & 5.2 & 6.0 & 6.8 & 7.0 & 6.8 & 6.6 & 6.5 \\
Banking and insurance & 0.5 & 0.5 & 0.6 & 0.9 & 1.2 & 1.4 & 1.7 & 1.7 \\
Administration, defense & 1.6 & 1.7 & 2.0 & 2.2 & 2.7 & 3.0 & 3.4 & 3.2 \\
Other services & 10.9 & 12.1 & 12.6 & 12.2 & 12.4 & 12.0 & 13.8 & 10.9 \\
Total & 100.0 & 100.0 & 100.0 & 100.0 & 100.0 & 100.0 & 100.0 & 100.0 \\
\hline
\end{tabular}

Sources: Statistical Yearbooks.

TABLE A2

EARNINGS ACCORDING TO THE BRANCH OF EMPLOYMENT (per cent)

\begin{tabular}{lrrrrrrrr}
\hline Branch & 1970 & 1980 & 1990 & 1991 & 1992 & 1993 & 1995 & 1997 \\
\hline Manufacturing industry & 101.8 & 103.8 & 103.8 & 103.6 & 103.5 & 101.3 & 99.7 & 100.5 \\
Construction & 114.8 & 110.2 & 109.9 & 106.6 & 108.2 & 112.3 & 108.1 & 104.9 \\
Agriculture & 94.0 & 101.2 & 109.6 & 97.7 & 91.8 & 87.7 & 84.2 & 79.5 \\
Transport and & & & & & & & & \\
$\quad$ communications & $\ldots$ & $\ldots$. & 104.6 & 103.2 & 99.1 & 97.5 & 100.8 & 105.8 \\
Trade and catering & 84.7 & 84.9 & 85.0 & 86.2 & 90.1 & 88.6 & 88.4 & 98.1 \\
Health and welfare & 91.1 & 92.0 & 92.6 & 96.6 & 94.5 & 95.0 & 92.1 & 90.0 \\
Education & 93.9 & 90.1 & 88.1 & 90.3 & 90.6 & 90.3 & 90.9 & 88.1 \\
Banking and insurance & 106.5 & 98.3 & 102.0 & 136.9 & 169.6 & 177.7 & 171.5 & 174.5 \\
Administration, defense & 101.0 & 100.7 & 100.4 & 105.3 & 114.6 & 117.8 & 117.6 & 110.2 \\
Total & 100.0 & 100.0 & 100.0 & 100.0 & 100.0 & 100.0 & 100.0 & 100.0 \\
\hline
\end{tabular}

Sources: Statistical Yearbooks. 
FIGURE A1

REAL INCOMES IN 1990-97 (1989 = 100)

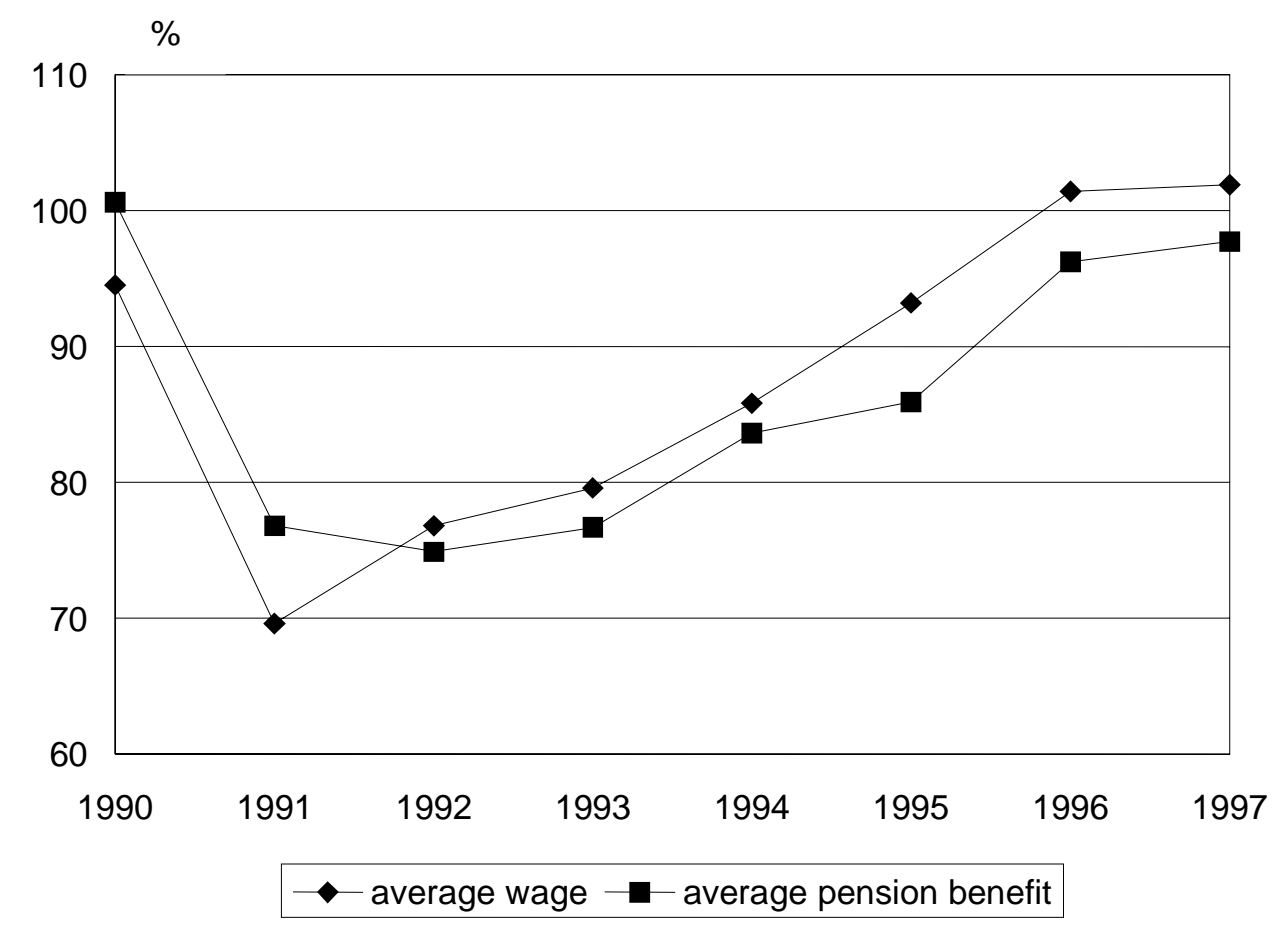

FIGURE A2

INCOMES OF THE POPULATION ACCORDING TO THEIR SOURCE (per cent)

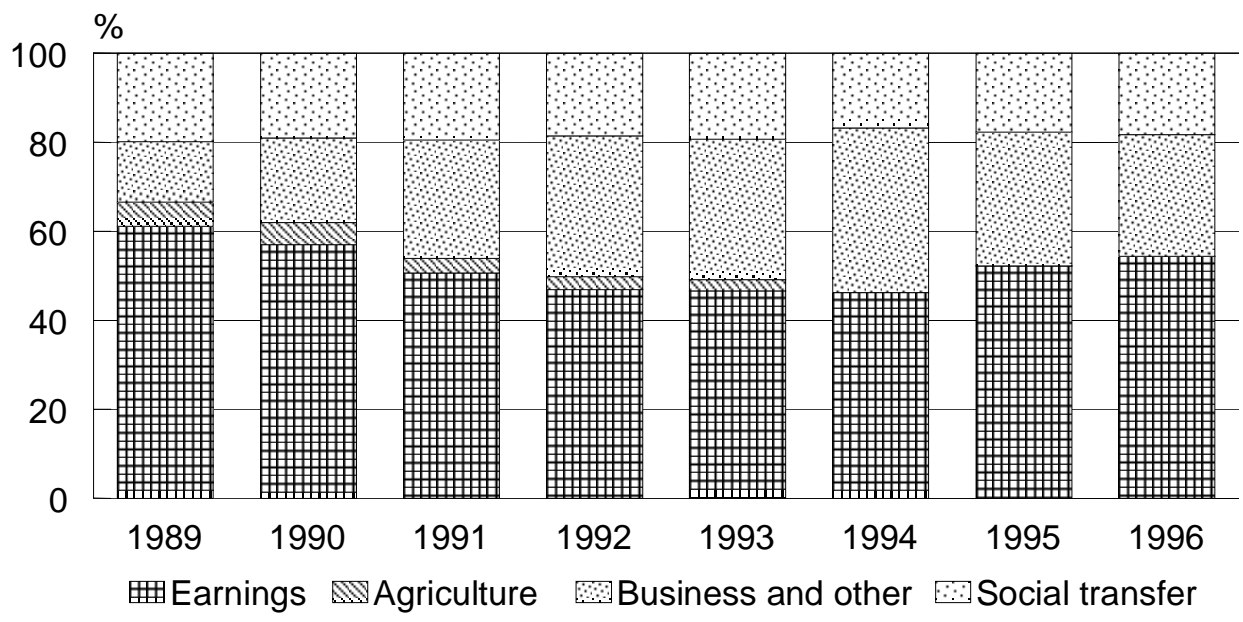

Source: Statistical Yearbooks and the Czech National Bank.

Note: There is a break of method between 1994 and 1995, when standard National Accounts replaced former Balance of Incomes and Expenditures of the Population. 


\section{REFERENCES}

Atkinson, A. B. and Micklewright, J. (1992), The Economic Transformation of Eastern Europe and the Distribution of Income, Cambridge: Cambridge University Press.

Becker, G. S. (1975), Human Capital: A Theoretical and Empirical Analysis, with Special Reference to Education, Chicago: University of Chicago Press.

Berger, P. L. (1986), The Capitalist Revolution. Fifty Propositions about Prosperity, Equality, and Liberty, New York: Basic Books.

Boguszak, M., Gabal, I. and Mateju, P. (1990), 'Concepts of social structure in Czechoslovakia' (in Czech), Sociologicky casopis 26 (2):168-186.

Erikson, R. and Goldthorpe, J. H. (1992), The Constant Flux. A Study of Class Mobility in Industrial Societies, Oxford: Clarendon Press.

Eyal, G., Szelenyi, I. and Townsley, E. (1998), Making Capitalism without Capitalists. The New Ruling Elites in Eastern Europe, Verso.

Fassman, M. (1997), 'International comparison of wages and productivity of labor with developed European countries' (in Czech), Pohledy 5 (6):23-52.

Featherman, D. L. and Hauser, R. M. (1984), Opportunity and Change, New York: Academic Press.

Ganzeboom, H., De Graaf, P. and Treiman, D. (1992), 'A standard international socioeconomic index of occupational status', Social Science Research 21: 1-56.

Gramsci, A. (1971), Selections from the Prison Notebooks, New York: International Publishers.

Hanley E., Mateju, P., Vlachova, K. and Krejci, J. (1998), The Making of PostCommunist Elites in Eastern Europe, Working Papers of the project Social Trends No. 4.

Kreckel, T. (1992), Politische Soziologie der sozialen Ungleichheit, Campus Verlag: Frankfurt/M.

Machonin, P. (1969), Czechoslovak Society. Sociological Analysis of Social Stratification (in Czech), Bratislava: Epocha.

Mateju, P. (1991), 'Who gains and who losses in a socialist redistribution' (in Czech), Sociologicky casopis 27(3):39-56.

Mateju, P. (1999), 'Social mobility and changes in perceived life-chances', in: Večerník, J. and Mateju, P. (eds).

Mateju, P. and Kreidl, M. (1998), The Crystallization of Social Status in the PostCommunist Society. The Czech Republic 1991-1997, Working Papers of the project Social Trends No. 7. 
Mincer, J. (1974), Schooling, Experience and Earnings, New York: National Bureau of Economic Research.

Mlcoch, L. (1995), 'The restructuring of property rights through the institutional economist's eyes', Prague Economic Papers 4 (2): 148-158.

O'Higgins, M. and Jenkins, S. (1990), 'Poverty in the EC: estimates for 1975, 1980 and 1985', in: Teekens, R. and Van Praag, B. (eds) Analyzing Poverty in the European Community, Luxembourg: EUROSTAT.

Opinions of citizen (1989) on selected questions of standard of living (in Czech), Prague: Institute for Public Opinion.

Orenstein, M. (1994), The political success of neo-liberalism in the Czech Republic, Working Papers No. 68, Prague: CERGE/EI.

Review (1995) of the Labour Market in the Czech Republic, Paris: OECD.

Sewell, W. H. and Hauser, R. M. (1975), Education, Occupation and Earnings, New York: Academic Press.

Sik, E. (1995), Measuring the unregistered economy in post-communist transformation, Vienna: European Centre for Social Welfare and Research.

Stark, D. (1992), 'Path dependence and privatization strategies in East Central Europe', East European Politics and Societies 6 (1).

Ullrich, Z. (1937), 'Social structure today' in: Bohac, A. (ed.) Population, Economic and Political Survey of Today (in Czech), Prague: Demografia.

Večerník, J. (1976), 'Change in income distribution in Czechoslovakia' (in Czech), Sociologicky casopis, 8 (5):472-485.

Večerník, J. (1991), 'The system of distribution in socialist Czechoslovakia: empirical data and explanatory hypotheses' (in Czech), Sociologicky casopis 26 (1):168-186.

Večerník, J. (1996), Markets and People. The Czech Reform Experience in a Comparative Perspective, Aldershot: Avebury.

Večerník, J. (1999a), 'The middle class in the Czech reforms. The interplay between policies and social stratification', Communist and Post-Communist Studies 32, pp. 397416 .

Večerník, J. (1999b), 'Inequalities in earnings, income and household wealth', in: Večerník, J. and Mateju, P. (eds).

Večerník, J. and Mateju, P. (eds) (1999), Ten Years of Rebuilding Capitalism. Czech Society after 1989, Prague: Academia.

Weber, M. (1956), Wirtschaft und Gesellschaft. Grundriss der verstehenden Soziologie I, Köln-Berlin: Kiepenheuer \& Witsch. 